\title{
Das casas às roças: comunidades de candomblé no Rio de Janeiro desde o fim do século XIX ${ }^{1}$
}

\author{
Roberto Conduru
}

\section{Práticas religiosas na Capital Federal após o fim da Abolição}

O primeiro texto mais abrangente sobre práticas religiosas com matrizes africanas no Rio de Janeiro é As religiōes do Rio, de João do Rio, pseudônimo de Paulo Barreto. Trata-se de um conjunto de reportagens publicadas, entre os meses de janeiro e março de 1904, na Gazeta de Notícias, no Rio de Janeiro, e reunidas em livro homônimo, publicado naquele mesmo ano. Nessa obra, de imediato, sobressai a diversidade de religiōes praticadas na então Capital Federal, após a abolição da escravatura. Já na introdução do livro, o autor diz: "ao ler os grandes diários, imagina a gente que está num país essencialmente católico, onde alguns matemáticos são positivistas. Entretanto, a cidade pulula de religióes. Basta parar em qualquer esquina, interrogar. A diversidade dos cultos espantar-vos-á". ${ }^{2}$

No conjunto diverso de religióes praticadas no Rio de Janeiro, também são múltiplas as tradiçóes religiosas africanas cultivadas. O mais extenso e consolidado relato de cunho memorialístico sobre religiōes afro-brasileiras no Rio de Janeiro é o livro Os candomblés antigos do Rio de Janeiro - as naçôes Kêtu: origens, ritos e crenças, publicado em 1994 e republicado, seis anos depois, por Agenor Miranda Rocha. Nessa obra, ele fala de crenças e práticas religiosas trazidas por africanos forçados a migrar ao Brasil em função do tráfico negreiro e da escravidão, as quais "deram origem ao que se convencionou denominar genericamente de religiões africanas no Brasil”. Ele também explicita a diversidade de tradições africanas, ao afirmar que "o termo candomblé é também genérico, pois engloba 'nações' diversas, tais como Angola, Kêtu, Congo, Jêje, Ijexá, Grunci, para citar somente as mais conhecidas”. ${ }^{3}$ Noventa anos antes, em suas reportagens, João do Rio falava dessa diversidade religiosa no Rio de Janeiro e de seus vínculos com as regiōes de onde os africanos foram trazidos forçadamente. No capítulo "Os feiticeiros", ele afirma que,

da grande quantidade de escravos africanos vindos para o Rio no tempo do Brasil colônia e do Brasil monarquia, restam uns mil negros. São todos de pequenas nações no interior da África, pertencem ao ijexá, oió, aboum, hauçá, itaqua, ou se consideram filhos de ibouam, ixáu, dos jejes e dos cabindas. ${ }^{4}$

Além das iniciações e dos cultos de orixás, voduns e inquices, João do Rio também dá notícia de que, no Rio de Janeiro, se cultuavam eguns - "Noutro dia, mais ou menos à meia noite, estávamos no ilê-saim ou casa das almas. O egungum é uma cerimônia quase pública” - e se jogava Ifá - "O velho babalaô indaga se é do seu gosto fazer o ifá". ${ }^{5}$ Alberto da Costa e Silva informa que Carmem Teixeira da Conceição, a Tia Carmem do Xibuca, "foi para o Rio de Janeiro em 1893, onde continuou a praticar a religião muçulmana. Já adulta, tornou-se católica”; além disso, Yara da Silva informa que ela também cultuava os orixás e era filha de Oxum. ${ }^{6}$

Antes de avançar, é preciso abrir um parêntese. Contrapondo textos de João do Rio e de Agenor Miranda Rocha, conjuga-se uma "visão de fora" a uma "visão de dentro", respectivamente, conforme classificação de Muniz Sodré e Luís Filipe de Lima. ${ }^{7}$ Com efeito, João do Rio era "de fora" - não era um iniciado, ou um adepto e, além disso, seu texto resulta de uma postura claramente preconceituosa em relação às religiões afro-brasileiras, assim como a todas as religiões que analisa em seu livro. Ao contrário, Agenor Miranda Rocha era "de dentro" - um iniciado, alguém do candomblé, da nação Kêtu e do Axé Opô Afonjá, embora transitasse por outras naçôes e casas, sendo respeitado pelo "povo do santo". Ambas as situações desses autores determinam visões particulares. E oferecem subsídios para compreender essas religióes no Rio de Janeiro. Não me parece ser o caso de demonizar um e santificar o outro. 
Embora o próprio João do Rio diga, a certa altura de seu livro, "que quis ter uma impressão vaga das casas e dos homens", ${ }^{8}$ Reginaldo Prandi afirma que As religioes do Rio contém "muitas páginas de deliciosa precisão e explicitíssimo preconceito". ${ }^{9}$ Marcelo Alves informa que João do Rio defendia com insistência seus escritos como "capítulos de livros documentativos". ${ }^{10}$ E Luís Rodolfo Vilhena acredita "poder encontrar nessa obra, para além de seus méritos de documento, alguns elementos que nos permitem discernir uma interessante reflexão sobre a natureza da experiência religiosa e, particularmente, das formas por ela assumidas no contexto urbano brasileiro". ${ }^{11}$ Por outro lado, é preciso observar as idiossincrasias da visão de Agenor Miranda Rocha, oriundas da singularidade de suas experiências nessa vertente do campo religioso, em sua nação, em seu axé; ele mesmo qualifica a primeira parte de seu livro como "um pequeno histórico sobre o candomblé de Kêtu no Rio de Janeiro". ${ }^{12}$ Articulando essas e outras fontes, visões "de dentro", "de fora" e que transitam entre "dentro" e "fora", procuram-se indícios que, ao se contraporem e serem criticados, permitam elaborar uma análise do processo histórico de constituição das comunidades de candomblé no Estado do Rio de Janeiro, focalizando a ocupação desse território, ao longo do tempo, por adeptos dessas religiōes, em suas práticas de reconfiguração das condições físicas e em sua condição como patrimônio cultural, com significados de cunho local, regional, nacional. Fim do parêntese.

Em decorrência da persistência do tráfico negreiro durante o século XIX, não surpreende as menções do cronista e do memorialista à presença de africanos na cidade. Ao dizer que "os pretos se odeiam intimamente, formam partidos de feiticeiros africanos contra feiticeiros brasileiros", ${ }^{13}$ João do Rio deixa entrever disputas por prestígio e poder na comunidade religiosa que persistem até hoje. Por vezes, a referência africana é algo genérica, como em uma menção dele a Sanin e "todas as suas fantasias, arrancadas ao sertão da África", ${ }^{14}$ assim como na lembrança de Agenor Miranda Rocha de uma amiga, "tia Antônia de Exu Biyi, feita de Exu na África", 15 "que vinha a ser prima carnal de Abedé". ${ }^{16}$ Em depoimento, Carmem Teixeira da Conceição fala de uma casa, na Pedra do Sal, que abrigava negros, "quando chegavam da África ou da Bahia": "tinha o sinal de que vinha chegando gente de lá. (...) Era uma bandeira branca, sinal de Oxalá, avisando que vinha chegando gente. A casa era (...) de um africano, ela chamava Tia Dadá e ele Tio Ossum, eles davam agasalho, davam tudo até a pessoa se aprumar”. ${ }^{17}$ Roberto Moura fala de "Quimbambochê, ou Bambochê (ou Bamboxê, como às vezes seu nome também é grafado) Obiticô, registrado como Rodolfo Martins de Andrade, africano que chega a Salvador num negreiro na metade do século XIX" ${ }^{18}$ Falando das "mães" e "filhas-de-santo", festeiras que promoviam encontros com sambistas em Oswaldo Cruz, Muniz Sodré menciona "Dona Martinha, africana de nascimento, madrinha da Portela". ${ }^{19}$

Em outras passagens, João do Rio dá indicações mais específicas quanto às origens africanas, ao falar dos "babalaôs de Lagos", dando a ver a presença de religiosos da região da atual Nigéria - uma presença que ainda hoje pode ser percebida, conforme depoimento de Babamikolé no Mapeamento dos terreiros de candomblé do Rio de Janeiro, organizado por Márcia Ferreira Netto,$-{ }^{20}$ e ao citar "Apotijá, mina famoso pelas suas malandragens", "um babaloxá da Costa da Guiné" e Ojê, "o tipo clássico do mina desaparecido". ${ }^{21} \mathrm{Na}$ "Relação dos processos e sentenças por atos de feitiçaria e prática ilegal de medicina”, publicada no livro Medo do feitiço, de Yvonne Maggie, além de dois portugueses, três portuguesas, um italiano e uma marroquina, aparece o processo contra um "cabo-verdiano, profissão curandeiro", em 1904. ${ }^{22}$ Roberto Moura fala "do formoso Assumano Mina do Brasil, negro malê". ${ }^{23}$

Também numerosas são as mençôes à presença de baianos na cidade. Além do já transcrito trecho do depoimento de Carmem Teixeira da Conceição, a evidenciar que as disputas se davam em meio à convivência entre africanos e baianos, João do Rio diz que "as casas dos minas conservam a sua aparência de outrora, mas estão cheias de negros baianos e de mulatos" . ${ }^{24}$ Já Roberto Moura oferece uma imagem sutilmente diversa, na qual os baianos guardam certa autonomia, ao dizer que 
os baianos se impõem no mundo carioca em torno de seus líderes vindos dos postos do candomblé e dos grupos festeiros, se constituindo num dos únicos grupos populares no Rio de Janeiro, naquele momento, com tradiçôes comuns, coesão, e um sentido familístico que, vindo do religioso, expande o sentimento e o sentido da relação consanguínea, uma diáspora baiana cuja influência se estenderia por toda a comunidade heterogênea que se forma nos bairros em torno do cais do porto e depois na Cidade Nova, povoados pela gente pequena tocada para fora do Centro pelas reformas urbanas. ${ }^{25}$

Agenor Miranda Rocha parece concordar com essa ideia, ao defender que

Ao longo da segunda metade do século XIX concentraram-se na cidade do Rio de Janeiro, em número significativo, negros baianos que constituíam um grupo à parte na massa de ex-escravos e seus descendentes que, na virada do século, estavam dispersos pela cidade, com ocupações variadas. ${ }^{26}$

Visão oposta tem Tiago de Melo Gomes, ao propor "que os baianos, por mais importantes que possam ter sido na constituição de uma cultura popular urbana na cidade do Rio de Janeiro, necessariamente dialogaram com tradições já existentes e com outros grupos recém-chegados". ${ }^{27}$ Arrematando o seu texto, ele diz:

Deve-se sempre ter em mente, enfim, que a experiência afro-brasileira na Corte, depois Capital Federal, é necessariamente multifacetada e não pode, de forma alguma, se restringir à trajetória de alguns indivíduos destacados em uma comunidade da região portuária da cidade. ${ }^{28}$

Com efeito, embora pareça ser proporcionalmente pequena, também é possível falar na presença de religiosos afros provenientes de outras regiōes brasileiras. Agenor Miranda Rocha informa que no Axé de Mesquita, fundado após 1926, por Dona Pequena de Oxalá e por seu marido, João Bankolê (Xangô), "juntou-se tia Bibiana (Oxalá) que veio de Recife". ${ }^{29}$ Tendo em vista que a Capital Federal era então um polo que atraía migrantes de diversas partes do país, a presença na cidade e na região fluminense de adeptos das religiôes com matrizes africanas provenientes de outros estados, é uma questão em aberto, a ser mais bem apurada pela continuidade das pesquisas.

Também havia o trânsito de pessoas naturais e/ou residentes no Rio de Janeiro para outras regiōes, na África e no Brasil. João do Rio informa que "alguns ricos mandam a descendência brasileira à África para estudar a religião", ${ }^{30}$ permitindo pensar que, além do enriquecimento de algumas famílias negras, havia conexōes diretas entre o Rio de Janeiro e a África, com o envio de afrodescendentes nascidos no Rio de Janeiro diretamente a regiões daquele continente, para formação religiosa. Entretanto, o mais comum devia ser a transmissão de valores e saberes entre gerações no próprio Brasil. É ainda João do Rio quem diz que "outros [ricos] deixam como dotes aos filhos cruzados daqui os mistérios e as feitiçarias". ${ }^{31}$

Parecem ter sido dominantes as conexôes entre o Rio de Janeiro e a Bahia, responsáveis pelo estabelecimento de redes de relações que se mantiveram e só cresceram com o passar do tempo. Se, ao falar da "morte de uma rapariga que fora à Bahia fazer santo", 32 João do Rio permite pensar que pessoas viajassem àquele estado para se iniciarem religiosamente, o mais frequente parece ter sido a dinâmica no sentido oposto: a migração de baianos para o Rio de Janeiro, onde constituíram comunidades religiosas, sem deixar de preservar os laços com suas comunidades religiosas na Bahia. Roberto Moura informa que "era comum as baianas de maior peso irem à Bahia tratar de suas coisas de santo e dos negócios de nação, progressivamente centralizados nas casas de candomblé de Salvador, como os negros baianos iam eventualmente à África". ${ }^{33}$ Agenor Miranda Rocha relata que João Alabá, de Omolu, "iniciou muitas filhas-de-santo"; Cipriano Abedé, de Ogum, "foi pai-de-santo de Dila e Maroca, ambas de Omolu e de Oya Bumi, entre outros", acrescentando que "dele [recebeu] os ensinamentos para tornar-(se) Olossaim"; Mãe Aninha, que estivera na então Capital Federal na segunda metade da década de 1880, "em 1925, volta à cidade, onde, no Santo Cristo, inicia sua primeira filha-de-santo do Rio, Conceição, de Omulu"; Benzinho Bamboxê, de Ogum, "iniciou muitos filhos de santo e era pai carnal de Regina 
Bamboxê, iyalorixá de casa na Raiz da Serra. Virgílio de Yansã, conhecido pai-de-santo do morro de São Carlos, também fez obrigação com Benzinho Bamboxê". ${ }^{34}$

Devido à dominância, quase onipresença, das narrativas sobre a atuação dos religiosos baianos no Rio de Janeiro, permanece a dúvida sobre a existência de conexões semelhantes da Capital Federal com outros estados brasileiros. Estabeleceram-se ao longo do tempo redes de relações entre comunidades religiosas do Rio de Janeiro e de outras regiōes do país? Outra questão a averiguar futuramente.

Também é importante destacar as comunidades formadas a partir de iniciações feitas por pessoas trazidas da África para o Rio de Janeiro, ou por seus descendentes residentes nessa cidade e nesse Estado. Um exemplo é a relação entre Rozena e Mejitó, conforme entrevista concedida por Agenor Miranda Rocha a Ari Araújo:

AA - Eu considero a figura de Mejitó muito importante, até porque ouvimos dizer que Tata Fomotinho foi quem trouxe o Jêje para o Rio de Janeiro e, sem querer diminuir em nada sua importância, acreditamos que isso se dê pelo fato de ele haver dado início, aqui, a uma grande e extensa família de santo, a qual nós nos orgulhamos de integrar. No entanto, me parece importante esclarecer que, quando Tata Fomotinho veio para o Rio de Janeiro, em 1930, já encontrou Mejitó, não é verdade?

AM - Mejitó foi feita por Tia Rozenda, foi a primeira casa de Jêje aqui do Rio de Janeiro. ${ }^{35}$

No já mencionado Mapeamento dos terreiros de candomblé do Rio de Janeiro, informa-se que "Guaiaku Rosena, africana, natural de Allada - Benim, que veio para o Brasil em 1864 (...), para o Rio de Janeiro, fundou um terreiro no bairro da Saúde, com o Asé Podabá-Jeje”. O que é confirmado por Mejitó Helena de Dan, bisneta-de-santo de Guaiaku Rosena, em seu depoimento contido nesse mapeamento: "O nosso [asé] aqui do Rio, especialmente o da minha casa, é o Jeje original, oriundo da África, mas não tem descendência da Bahia. É Jeje do Rio de Janeiro mesmo". ${ }^{36}$

Mejitó Helena de Dan foi iniciada por Natalina de Aziri, que fora iniciada por Ontinha de Oyá, uma das filhas-de-santo de Guiaku Rosena. Mas essa é uma rede de transmissão de axé estabelecida em momentos posteriores ao analisado até aqui. O que nos conduz a uma reflexão sobre o tempo no processo de constituição das comunidades de candomblé no Rio de Janeiro.

\section{Tempos}

Embora marcada pela lógica da nação Kêtu e, particularmente, pela trajetória de sua mãe-de-santo, Aninha de Xangô, e do axé por ela criado, o Opô Afonjá, a narrativa de Agenor Miranda Rocha pode ser tomada como base para se pensar o processo de consolidação das comunidades de candomblé no Rio de Janeiro ao longo do tempo. O capítulo "As casas de Kêtu no Rio de Janeiro", de seu livro As naçôes Kêtu: origens, ritos e crenças, é estruturada em quatro momentos.

\section{1. Primeiro momento: da segunda metade do século XIX à década de 1930}

O primeiro período estende-se desde um início difuso, que se adensa na segunda metade do século XIX, e ganha mais consistência no fim daquele século e nas primeiras décadas do século seguinte, quando, "nos bairros centrais, instalaram-se (...) outras casas de santo, dirigidas por nomes ilustres, entre os quais destacam-se Abedé, Guiaku e Rozena” ${ }^{37}$, além do anteriormente citado João Alabá. Naquele momento, as práticas religiosas afro-brasileiras eram perseguidas e reprimidas pela polícia civil, que atuava seguindo o artigo 157 do Código Penal de 1890, que previa punição para "o espiritismo, a magia e seus sortilégios". Código que, desde a sua promulgação, "foi considerado como incapaz de dar conta dos novos desafios colocados pelas transformaçōes sociais e políticas do período republicano". ${ }^{38}$

No relato de Agenor Miranda Rocha, esse período estende-se até os anos 30, com as mortes de Rodolfo Bamboxê, de João Alabá, em 1926, de Cipriano Abedé, em 1933, e de Mãe Aninha, em 1938. ${ }^{39} \mathrm{O}$ fim da vida dessas lideranças religiosas coincide com mudanças na legislação, com a pro- 
mulgação do decreto 1.202, de 8 de abril de 1939, lei federal que deixou de autorizar a perseguição e a repressão das práticas religiosas afro-brasileiras.

Em seu livro O banquete do rei..., José Flávio Pessoa de Barros afirma que "as comunidades Jêje encontradas no Rio de Janeiro à época eram as de Rozena de Besseim (Azinossibale); a de Domotinha de Oiá (Vodum Zevode) e a de Natalina de Oxum; todas também no centro da cidade, região da Saúde". ${ }^{40}$ Sobre as comunidades pertencentes à nação Angola, o mesmo autor defende que "o pioneiro desta religiosidade de origem Bantu, (é) Joãozinho da Gomeia, que aqui se estabeleceu na década de trinta". ${ }^{41}$ Contudo, de acordo com Antonio Carlos Peralta, Joãozinho da Gomeia instalou-se em Duque de Caxias apenas em 1947, apesar de ter tentado radicar-se no Rio de Janeiro cinco anos antes. ${ }^{42}$

Encontramos, também, a informação de que João Correira de Melo, conhecido como João Lesenge, membro da comunidade do Bate Folha baiano, migrou para o Rio de Janeiro da década de 30 e comprou, em 1938, "um terreno com aproximadamente 5.000 metros quadrados, no bairro Anchieta, fundando ali, o Bate-Folha do Rio de Janeiro (Kupapa Unsaba), preservando, em pleno subúrbio, a língua quimbundo e os ritos de origem banta". ${ }^{43}$ Ainda da nação Angola, o Mapeamento dos terreiro de candomblé do Estado do Rio de Janeiro recupera uma comunidade ausente na bibliografia até aqui utilizada: o Ilê Asé Baba Olwô Omin, fundado em Pendotiba, Niterói, em 1938, por João Gambá, que desenvolvia suas práticas religiosas desde $1910 .{ }^{44}$

\subsection{Outros parênteses: (des)continuidade na vida das comunidades de candomblé}

$\mathrm{Na}$ narrativa de Agenor Miranda Rocha, o segundo momento se dá após o falecimento de algumas lideranças religiosas, nos anos 20 e 30, quando "três das quatro casas existentes até então fecharam, levando à dispersão das pessoas iniciadas em cada uma delas. Esse processo de dispersão foi acompanhado pela abertura de novas casas, em moldes bem diferentes dos padrões até então encontrados". ${ }^{45}$ Assim, cabe abrir outro parêntese, para pensar tipos de continuidade das comunidades de candomblé no Rio de Janeiro.

Além de questôes pessoais, particulares a cada uma das comunidades religiosas, os seus destinos podem e devem ser considerados em função das dinâmicas da vida na cidade. Um caminho para pensálos é a análise de Roberto Moura sobre os rumos da distinção constituída pelos africanos e pelos baianos da nação iorubá na comunidade popular, garantida "por suas tradições civilizatórias e coesos pelo culto do candomblé":

As características do desenvolvimento da cidade e de seus bairros populares e a sucessão de gerações em meio a um processo de massificação cultural imposto tornariam cada vez mais difícil esse exclusivismo. Assim, incorporam-se progressivamente aos seus descendentes, principalmente a partir de 1930, indivíduos de diversas procedências, a partir da solidariedade despertada tanto nas órbitas de vizinhança e trabalho, quanto a partir da complexidade de encontros e influências que a vida ganha no Rio. ${ }^{46}$

Sobre o fechamento das casas, pode-se arriscar a dizer que, a rigor, todas as casas abertas naquele momento tiveram algum tipo de descontinuidade. Em seu livro, Agenor Miranda Rocha informa que

Em 1886, Mãe Aninha, de Xangô, veio ao Rio com Bamboxê e Oba Saniá, com os quais fundou uma casa no bairro da Saúde. Retorna à Bahia, onde funda, em 1910, a Roça do Retiro. Em 1925, volta à cidade, onde, no Santo Cristo, inicia sua primeira filha-de-santo do Rio, Conceição, de Omulu. Com o seu falecimento em 1938, sua sucessora, Agripina de Souza - de Xangô -, transfere o axá [sic] para Coelho da Rocha. ${ }^{47}$

Contudo, depois, ele apresentou esse processo de modo um pouco diferente:

Mãe Aninha, já em 1885, segundo diz o povo, esteve no Rio pela primeira vez, acompanhada de tio Joaquim e Rodolfo Bamboxê, ficando na Pedra do Sal, também na Saúde. Em 1925, ela retorna ao Rio, desta feita para a casa de sua irmã-de-santo, Maria Ogalá, de Oxaguiã - casada com João Cavalcante, iniciado por Pulquéria - e funda uma casa de Candomblé na Gamboa, na Rua Comendador Leonardo, onde fez a 
primeira iaô do Rio de Janeiro: Conceição de Obaluaê, que foi a mãe do Ogã Bila. Em 1929, funda outra casa, onde ela colocou os santos, na Rua Alegre, em um bairro chamado Aldeia Campista, e aí faz o santo de Alberta de Oxum. Depois coloca um axé em um terreno de Coelho da Rocha, de Conceição e seu filho, o Ogã Bila ou Pai Bila, como costumávamos chamá-lo. Ele ficou muito tempo como alabê, encarregado dos atabaques, para Agripina, que tomou conta deste axé até sua morte, sendo, então, sucedida por minha irmã Cantulina. ${ }^{48}$

Diferenças sutis também podem ser encontradas em visões mais recentes da atuação de Mãe Aninha no Rio de Janeiro. Ao editar uma correspondência da fundadora do Opô Afonjá, Luis Nicolau Parés informa que, na viagem à Capital Federal, em 1886, Mãe Aninha, Bamboxê e Oba Saniá "acharam uma casa com um assentamento de Xangô Afonjá na Pedra do Sal (...). Ela limpou o local e deixou alguém tomando conta, voltando logo os três para Salvador" ${ }^{49}$ Ao apresentar essa correspondência, João Batista dos Santos Tobiabá acrescenta que "Aninha não fez nenhuma iniciação" em 1925. E informa que

Em 1930, houve uma terceira viagem mais prolongada e mãe Aninha ficou no Rio de Janeiro por cinco anos, até 1935. Desta vez, Agripina, acompanhada de seu marido e do seu filho carnal Fernando, e sua irmã Filhinha de Oxum, que tinha ficado viúva recentemente, foram também para lá. Residiam todos juntos em casa espaçosa, na rua Alegre no 923-A, e lá tinham sua clientela. ${ }^{50}$

Independentemente das pequenas diferenças existentes nesses relatos e interpretações, que ainda estão por serem confrontados, as várias narrativas fazem supor a existência de tipos diversos de fechamento, de fim e de continuidade, ou de descontinuidade, próprios às práticas religiosas afros no Rio de Janeiro de então. Esses relatos indicam modalidades variadas de transmissão e persistência das tradições religiosas. Um tipo de preservação de axé pode ser observado quando os axés constituídos por um indivíduo foram trasladados, de um local a outro, por pessoas por ele iniciadas, sendo mantidos por seus herdeiros até hoje. Este é exatamente o caso da comunidade fundada por Mãe Aninha, o Axé Opô Afonjá.

Outro tipo de preservação de axé é a herança de assentamentos e outros elementos, que passam a ser cuidados por pessoas não necessariamente iniciadas pelo indivíduo a quem os mesmos se referem. É o caso do assentamento de João Alabá. Agenor Miranda Rocha comenta que ele "faleceu sem deixar sucessor e, após algum tempo, a casa foi fechada", acrescentando que "a falecida Dona Pequena, de Oxalá, herdou o Omolu de João Alabá e com ele fundou o Axé de Mesquita”. Obtivemos a informação de que Vicente Bankolé e Tia Pequena estiveram, primeiro, em Bento Ribeiro e, logo em seguida, se estabeleceram em Mesquita, na Baixada Fluminense, criando "a Sociedade Beneficente da Santa Cruz de Nosso Senhor do Bonfim, mais conhecida como Casa-Grande de Mesquita, e que seria a primeira comunidade-terreiro de candomblé a estabelecer-se na Baixada Fluminense”. Após a morte de Dona ou Tia Pequena, esse axé foi transmitido a "Dona Davina (Omolu), filha-de-santo de Procópio de Ogunjá, que na época era mãe pequena do axé". Após a morte dela, em 1964, a "sua neta carnal Meninazinha (Oxum), também sua filha-de-santo, herdou os santos da avó e anos mais tarde veio a se tornar uma conhecida mãe-de-santo, tendo aberto sua própria casa, dando continuidade à tradição da família", ${ }^{51}$ o Ilê Omolu Oxum. Caso semelhante é o de Mãe Edelzuita de Oxaguian, do Ilê Oba Nila, a qual, segundo o já mencionado mapeamento, "herdou a pedra de Xangô Agodô trazida por José Caime" do Daomé, atual Benim, que foi passada a ela "por sua mãe-de-santo em 1944". 52

Um terceiro tipo de preservação de axé é observado quando há continuidade na descendência religiosa, embora os axés e as comunidades constituídos não sejam preservados. É o caso de Regina Bamboxê, descendente de Rodolfo Bamboxê, que não deu continuidade à comunidade por ele criada nas imediações da Praça Onze, constituindo uma para si em Raiz da Serra. Um segundo exemplo desse tipo de continuidade de axé é o da descendência religiosa de Guaiaku Rosena, cuja casa foi herdada por Ontinha de Oyá e por ela transferida para Coelho da Rocha; "quando faleceu [Ontinha de Oyá], deixou uma herdeira que não deu continuidade ao asé". Contudo, uma outra filha-de-santo de Guaiaku Rosena, "Natalina de Aziri, descontente, fundou o Kwe Sinfá, em Augustinho Porto, São João de 
Meriti”, cujo imóvel, após sua morte, foi vendido por sua família carnal. Mejitó Helena de Dan, sua filha-de-santo, "herdou o asé e tomou conta dos santos de Natalina durante 14 anos, até comprar o terreno e reabrir o terreiro em 1995, no Parque Paulista, em Duque de Caxias", dando continuidade ao Asé Podabá-Jeje. ${ }^{53}$

Com essas considerações, fechamos o parêntese e retornamos à divisão temporal do processo de constituição das comunidades de candomblé do Rio de Janeiro.

\subsection{Segundo momento: os anos 40}

Na narrativa de Agenor Miranda Rocha,

A década de 40 marca uma nova fase do candomblé carioca. Três das quatro casas existentes até então fecharam, levando à dispersão das pessoas iniciadas em cada uma delas. Esse processo de dispersão foi acompanhado pela abertura de novas casas, em moldes bem diferentes dos padrōes até então encontrados. As novas lideranças religiosas emergentes na cidade deixam os bairros urbanos pobres e se deslocam para o subúrbio, onde instalam suas "roças". ${ }^{4}$

Além do Opô Afonjá, em Coelho da Rocha, e das comunidades de Meninazinha d'Oxum, em São Mateus, e de Regina Bamboxê, em Raiz da Serra, José Flávio Pessoa de Barros refere-se a outras comunidades entre as "muitas outras fundadas a partir da tradição dessas comunidades iniciais": "a casa-de-santo de Pai Ninô em Camari, Nova Iguaçu; a de mãe Dila, filha de Cipriano Abedé, em São João de Meriti”. 55

Nesse período não cessa a vinda de baianos para o Rio de Janeiro. O mesmo autor também trata da constituição, por baianos, de comunidades da nação Efon na cidade, à época:

No final da década de quarenta, vem para a então capital da República, Rio de Janeiro, Cristóvão d'Efon, isto é, da nação Efon, subgrupo Nagô, aqui iniciando várias pessoas, dando origem a uma linhagem muito profícua. Surgem, então, várias comunidades oriundas desta casa original de Salvador, como as de Valdomiro de Xangô, Francisco de Iemanjá, Regina de Oxossi, e muitas outras. ${ }^{56}$

De acordo com o Mapeamento dos terreiros de candomblé do Rio de Janeiro, Valdomiro de Xangô, da nação Efon, criou, no final dos anos 40, o Ilê Asé Baru Lepé, também denominada como Tenda Santo Antônio dos Pobres, no Parque Fluminense, em Duque de Caxias. ${ }^{57}$ Segundo o sítio eletrônico do Axé Tumba Junsara, Manoel Ciriaco de Jesus, fundador do Tumba Junsara de Salvador, em 1919, também fundou o Tumba Junsara em Vilar dos Teles, "por volta de 1946". ${ }^{8}$

\subsection{Terceiro momento: os anos 50 e 60}

O terceiro período indicado na narrativa de Agenor Miranda Rocha compreende as décadas de 50 e 60. Se o primeiro momento é caracterizado pela constituição de comunidades de candomblé na região central da cidade, enquanto o segundo momento é marcado pela transferência de algumas dessas comunidades para o subúrbio e a Baixada Fluminense, na avaliação de Rocha, os anos 50 e 60 "podem ser consideradas como os 'anos de ouro' do candomblé no Rio de Janeiro”. E ele diz por quê:

Esse período é sempre lembrado não apenas nas casas de Kêtu, mas em todas as tradições então instaladas na cidade. Com as roças estruturadas, muitas festas se tornaram famosas. Um grande público, proveniente dos bairros de classe média e alta da cidade, frequentava os subúrbios por ocasião dessas festas. As casas mais concorridas eram o Bate-Folha, em Anchieta (nação de Congo, casa do finado João Lessengue), o Axé Opô Afonjá, em Coelho da Rocha (nação de Kêtu, com Mãe Agripina). E principalmente a casa do mais famoso pai-de-santo da cidade: Joãozinho da Gomeia, o chamado "rei do Candomblé", em Caxias. 59

Nesse período, não cessa de crescer a migração de religiosos baianos para o Rio de Janeiro, uma das características das religiões afro-brasileiras nesse estado. Sobre as comunidades Jêje no Rio de Janeiro, José Flávio Pessoa de Barros informa "a vinda para o Rio de Janeiro, de Tata Fomotinho, que aqui vai 
fundar seu terreiro e originar uma extensa linhagem, (...) por volta dos anos 50" ${ }^{60}$ Outra nação africana chega da Bahia nessa época, de acordo com José Flávio Pessoa de Barros: "ainda na década de cinquenta, a nação Ijexá também se transfere para o Rio de Janeiro, através de Zezito de Oxum, neto de Eduardo de Ijexá, Pai-de-santo famoso, um dos últimos de sua linhagem em Salvador" ${ }^{61}$ Tendo chegado ao Rio de Janeiro em 1958, Pai Zezito fundou sua casa, dois anos depois, em Belford Roxo. ${ }^{62}$

Além do axé de Pai Zezito, o Mapeamento refere-se a outros baianos que constituíram comunidades religiosas no Rio de Janeiro, nessa época: Zezinho da Boa Viagem, criador da Associação Religiosa Terreiro Jêje-Mahin da Boa Viagem, em Nova Iguaçu, em 1957; e Yá Kauendê, da nação Angola, que funda o Abassá de Ogum, em Santo Elias, Mesquita, em 1956.

O fluxo de baianos para o Rio de Janeiro parece ter sido intermitente, pois Barros assinala que, "a partir de 1960, nova migração ocorre para o Rio de Janeiro". Ele informa que "nessa década também chegaram, e aqui no Rio de Janeiro se estabeleceram, outras comunidades Ketu, originadas das tradicionais casas baianas". ${ }^{33}$ "Do Alaketu da Bahia veio Beata de Iemanjá e Delinha d'Ogum, que estabelecem os seus terreiros em Miguel Couto, Nova Iguaçu; e Janete d'Oxum, na Ilha do Governador". Do Ilê Axé Iyá Nassô Oká, a Casa Branca do Engenho Velho, vieram e se estabeleceram: "Nitinha d'Oxum, em Miguel Couto, município de Nova Iguaçu; Tete de Oiá, em Guadalupe; Elza de Iemanjá, em Villar dos Telles, São João de Meriti; e Amanda d'Obaluaiê, em Coelho da Rocha, no município de mesmo nome". Do Gantois,

Marina de Ossaim funda o seu terreiro em Belford Roxo; Letícia d'Omolu, em Nova Iguaçu; Almerinda d'Oxossi, em Quintino; Edeusuíta d'Oguiā, em Jacarepaguá; Lindinha d'Oxum, em Villar dos Teles - São João de Meriti; Margarida d'Oxum, em Vila Valqueire; Bida de Iemanjá em Cascadura; Marta d'Oxum e Simone d'Oxossi, em São Gonçalo.

E acrescenta:

Do local chamado Engenho Velho de Cima, à mesma época, chegam Álvaro - Pé Grande, fundando seu Axé em Jacarepaguá e, ainda no mesmo bairro, em Salvador, porém da Casa de Oxumarê, Benta de Ogum, que se fixou em Cabuçu, município de Nova Iguaçu, Teodora d'Iemanjá e Tomazinha d'Oxum, que estabelecem residência em Villar dos Teles.

José Flávio Pessoa de Barros informa, ainda que "vieram da Ilha de Itaparica, ligados ao culto dos ancestrais Babá-Egum, estritamente masculino, os sacerdotes Laércio e Braga, respectivamente para Villar dos Teles e Caxias". ${ }^{44}$ A estes, Gisele Omindarewá Cossard acrescenta "o Ilekê, dirigido por ojé Joziel, no Cabuçu, Niterói” ${ }^{65}$. Encontramos no Mapeamento, a informação de que Josiel Manuel dos Santos, baiano vindo para o Rio de Janeiro em 1962, foi iniciado no Abassá de Ogum por sua tia, Yá Kauendê, e indicado como herdeiro do axé após a morte dela. Em 1986, transferiu o terreiro de Mesquita para Nova Iguaçu e, após a sua iniciação no culto de babaegum, na Bahia, em 1999, passou a direção do Abassá de Ogum a Ronaldo de Oxaguian e fundou o Ilê Asé Baba Nile Ke, em 2001, em terreno ao lado do Abassá de Ogum. ${ }^{66}$

Sem especificar quando vieram para o Rio de Janeiro, José Flávio Pessoa de Barros ainda menciona, da origem Jêje,

as comunidades de Margarida d'Iemanjá, única representante do Bogum de Salvador, e de Waldirzinho de Oxumarê, originário da Casa de Enoque, em Cachoeiras de São Feliz. A primeira funda seu Axé em Villar dos Teles, e o último, na localidade de Raiz da Serra. ${ }^{67}$

Com esses dados, delineia-se um panorama extenso de comunidades de candomblé no Rio de Janeiro vinculadas a comunidades baianas de várias naçôes, em paralelo à continuidade das comunidades anteriormente constituídas na cidade e na região. Analisando a constituição do "candomblé paulista", Reginaldo Prandi diz que "por volta de 1960, havia um trânsito importante entre Rio e São Paulo, 
entre umbanda e candomblé, trânsito que trazia o candomblé para dentro da umbanda e o Rio para dentro de São Paulo". ${ }^{68}$ Análise interessante e importante, nesse contexto, pois confirma a condição do Rio de Janeiro como polo de constituição, recepção e difusão de tradições religiosas afro-brasileiras.

\subsection{Quarto momento: dos anos 70 aos dias atuais}

Finalmente, na visão de Agenor Miranda Rocha, o quarto período estende-se desde os anos 70, quando "outras casas foram abertas no Rio de Janeiro através da transferência de pessoas iniciadas em importantes casas de tradição de Kêtu”. Segundo José Flávio Pessoa de Barros, "a maioria das casas (das mais diferentes nações) estão localizadas no perímetro urbano da cidade do Rio de Janeiro, região chamada Baixada Fluminense, que hoje abriga mais de três mil e oitocentas casas-de-candomblé de diversas origens". Ele estabelece esse quantitativo, a partir da reportagem "Um Rio de atabaques", publicada na edição número 1.471 da revista Isto É, de 10/12/1997, que afirma existirem mais terreiros de candomblé no Rio de Janeiro do que na Bahia. ${ }^{69}$ Independentemente desses números e proporções que, passada mais de uma década, precisam ser confirmados, é inquestionável a existência de fortes vínculos entre as comunidades de candomblé do Rio de Janeiro e da Bahia, estabelecidas e preservadas desde o século XIX.

\subsection{Tempo(s) e espaço(s)}

Em que pese a pertinência dessa subdivisão em quatro períodos - sempre passível de revisão, a partir de outras pesquisas e reflexões - o processo de constituição das comunidades de candomblé no Rio de Janeiro indica situações espaciais distintas. Primeiro, no que tange à localização das práticas e comunidades de candomblé na cidade e no Estado do Rio. Depois, em relação à conformação dessas comunidades, com implicaçôes importantes para suas práticas e valores.

\section{Espaços do candomblé no Rio de Janeiro}

\subsection{Distribuição territorial das comunidades de candomblé}

Em um dado momento de sua reportagem, quando apresenta as pessoas e as casas que conheceu por meio de Antônio, seu guia no campo religioso afro-brasileiro, João do Rio informa que "no trajeto que fizemos do largo da Carioca à Praça da Aclamação, encontramos, afora um esverdeado discípulo de Alicali, Omancheo, como eles dizem, duas mães-de-santo, um velho babalaô e dois babaloxás" ${ }^{70}$ Esse relato permite-nos observar como esses religiosos e suas práticas se faziam presentes em espaços urbanos de uso coletivo. Dizendo ter perguntado a seu informante se havia "muitas mães-de-santo", João do Rio conta que recebeu uma resposta com certa precisão quantitativa: "Umas 50". Em seguida, Antônio enuncia vários nomes, alguns dos quais associados a lugares que podem ser aqueles nos quais essas religiosas atuavam e/ou residiam: "a Henriqueta da Praia, a Maria Marota, que vende à porta do Glacier, a Maria do Bonfim, a Martinha da rua do Regente, (...) a Dudu do Sacramento". ${ }^{71}$

Também é possível depreender que fossem prestados serviços a domicílio, pois João do Rio diz ter acompanhado por dois dias o "babaloxá da Costa da Guiné (...) a lugares onde havia serviço" e tê-lo visto "misteriosamente, entrar em casas de Botafogo e da Tijuca, onde, durante o inverno há recepções e conversationes às cinco da tarde como em Paris e nos palácios da Itália" ${ }^{72}$ Ao contar como sua avó, Tia Ciata, curou "um encosto" em Wenceslau Brás, Bucy Moreira informa que, apesar de ela insistir em atender o presidente em sua casa, com a sentença "quem precisa de caridade que venha cá", finalmente "ela foi lá fazer o serviço". ${ }^{73}$

O depoimento do neto de Tia Ciata também deixa entrever a existência de espaços fixos de iniciação, vivência e atuação religiosa. O que se confirma na reportagem de João do Rio, que menciona a existência de "ilê axé ou ilê orixá" 74 e informa onde se localizavam. No capítulo "Os feiticeiros" de seu 
As religiōes do Rio, ele diz ter conhecido "as casas das ruas de São Diogo, Barão de São Félix, Hospício, Núncio e da América, onde se realizam os candomblés e vivem os pais-de-santo". ${ }^{75}$ Agenor Miranda Rocha confirma esses dados, ao identificar um foco no processo de ocupação espacial pelos negros no Rio de Janeiro de então, afirmando que, enquanto a "massa de ex-escravos e seus descendentes (...) na virada do século, estavam dispersos pela cidade, com ocupações variadas", a maioria dos baianos

vivia nos bairros centrais da cidade: Saúde, Gamboa e Santo Cristo. O crescimento das atividades portuárias e a inauguração da estação de estrada de ferro nas proximidades transformaram essa região num polo de atração de população pobre. Os antigos casarôes transformaram-se em cortiços e as chácaras foram sendo loteadas, fazendo surgir um emaranhado de ruelas, becos e casas. Nessas casas e cortiços residiam muitas das pessoas que se reuniram para fundar as primeiras casas de candomblé da cidade. João Alabá, talvez o mais famoso, morava na Rua Barão de São Félix, no centro da cidade.

Também nos bairros centrais, instalaram-se, em fins do século passado e no início deste século, outras casas de santo, dirigidas por nomes ilustres, entre os quais destacam-se Abedé, Guaiaku e Rozena. ${ }^{76}$

Entre as pessoas que conheceu nos três meses em que diz ter vivido no meio de "mais de cem feiticeiros, mais de cem...", João do Rio cita vários nomes, alguns com endereço preciso: "A Assiata ("uma negra baixa, fula e presunçosa") mora na rua da Alfândega, 304"; "o Titino, da rua Frei Caneca"; "Obitaiô, da rua Bom Jardim”; "a Dudu do Sacramento, que mora também na rua Bom Jardim”; "Apotijá, mina famoso pelas suas malandragens, que mora na rua do Hospício, 322"; "o Jorge da rua do Estácio"; "o João Mussê, alufá feiticeiro tremendo, que mora na rua Senhor dos Passos, 222 e é respeitado por todos"; "a casa de Ojô fica na rua dos Andradas, quase no começo"; "Abubaca Caolho, o alcoólico da rua do Resende"; o "celebrado João Alabá, negro rico e sabichão da rua Barão de São Félix, 76" ${ }^{77}$

Agenor Miranda Rocha confirma algumas dessas indicações e oferece outras. Além de informar que "tinha Tio Sanin, no Morro do Pinto", ${ }^{78}$ precisa a localização do que ele entende como as "quatro primeiras casas" da nação Kêtu no Rio de Janeiro:

Na rua Barão de São Félix, no bairro da Saúde, João Alabá, de Omolu, abriu uma das primeiras casas de santo da cidade. (...)

Inicialmente, na Rua do Propósito, e depois, na Rua João Caetano, Cipriano Abedé, de Ogum, abriu sua casa. (...)

Em 1886, Mãe Aninha, de Xangô, veio ao Rio com Bamboxê e Oba Saniá, com os quais fundou uma casa no bairro da Saúde. (...)

Na Rua Marquês de Sapucaí, Benzinho Bamboxê, de Ogum, funda sua casa. ${ }^{79}$

E Roberto Moura informa que Assumano Mina do Brasil, africano e muçulmano "que trabalhava com os astros", "morava num sobrado na praça Onze, 191". ${ }^{80}$

Entretanto, no primeiro momento delineado por Agenor Miranda Rocha, essas comunidades de candomblé não estavam restritas à região "que se estendia da zona do cais do porto até a Cidade Nova, tendo como capital a praça Onze", a qual Heitor dos Prazeres qualificou como Pequena África, ${ }^{81}$ e como África em miniatura. ${ }^{82}$ Tobiabá diz que, em sua estada no Rio de Janeiro, em 1925, Mãe Aninha "ajudou sua amiga Sinhá Maria Ogalaá de Oxaguiã na feitura de uma mão de Maria da Conceição, iaô de Omolu, na rua São Luiz Gonzaga n ${ }^{\circ}$ 49. Também lavou contas para Clarice Feitosa, na rua Comendador Leonardo", permitindo observar como as práticas religiosas de Aninha se realizaram em diferentes partes da cidade: na Gamboa, na Pequena África, e em São Cristóvão. ${ }^{83}$ Em depoimento incluído no Mapeamento, Mãe Regina Lúcia de Iemanjá, atual Yalorixá do Asé Opô Afonjá, comenta que esse Asé "esteve no Rocha, Cavalcante e chegou aqui em Coelho da Rocha. Não era bem esse local, era lá na esquina. Depois, então, é que passou para cá". ${ }^{84}$

João do Rio também menciona "uma casa nas imediações da praia de Santa Luzia". ${ }^{55} \mathrm{Na}$ "Relação dos processos e sentenças por atos de feitiçaria e prática ilegal de medicina”, Yvonne Maggie indica alguns locais onde aconteceram práticas religiosas afro-brasileiras nessa época: no Andaraí e no Morro 
de Santo Antônio, em 1898; em Madureira e na rua do Lavradio, em 1899; no Morro de São Carlos, em 1930; e no Morro do Pinto, sem indicação de data. ${ }^{86}$ Muniz Sodré informa outro caso de violência policial contra religiosos negros, acontecido no morro do Salgueiro, em 1916, a partir de uma notícia do jornal Correio da Manhä. ${ }^{87}$

Ainda em relação à localização de terreiros e casas, Agenor Miranda Rocha informa que Adelaide Mejitó, filha de Tia Rozena, "morou muitos anos em Cavalcante, depois mudou-se para Coelho da Rocha". ${ }^{88}$ Tratando das festas realizadas fora das escolas de samba, Roberto M. Moura recupera que "as mais famosas (festas) de Oswaldo Cruz eram na casa da Dona Esther, uma espécie de Tia Ciata do subúrbio da Central". Sobre Oswaldo Cruz, Muniz Sodré acrescenta:

Este bairro era um reduto importante de formas culturais negras (...). Em quintais diversos, realizavam-se reuniōes de jongo (canto e dança de linha mística com pontos e desafios, de onde se deriva o samba de partido alto), caxambu (forma semelhante ao jongo, mas com diferenças rítmicas) e rodas de samba. Além disto, havia as 'mães-de-santo' e 'filhas-de-santo' festeiras (como Dona Martinha, africana de nascimento, madrinha da Portela), que promoviam encontros com sambistas. ${ }^{89}$

No artigo já mencionado de Tiago de Melo Gomes, é possível recuperar a presença de "Seu Alfredo, 'mulato mineiro', 'mestre-sala dos bons, pai-de-santo e jongueiro'”, fundador do bloco Cabelo de Mana, origem da Escola de Samba Império Serrano, na Serrinha, em Madureira, e de "Maria Rezadeira, jongueira da Mangueira e nascida em Valença [Estado do Rio de Janeiro], em 1902, neta de africanos e índios, que aprendeu a prática em sua infância na fazenda Bem Posta”. ${ }^{0}{ }^{0}$

Somando a grande quantidade de referências espaciais até aqui reunidas, pode-se dizer que tanto as práticas quanto as comunidades religiosas com referências africanas se estendiam por toda a cidade do Rio de Janeiro. No comentário preconceituoso de João do Rio, "não há ninguém cuja vida tivesse decorrido no Rio sem uma entrada nas casas sujas onde se enrosca a indolência malandra dos negros e das negras" ${ }^{91}$ E acrescenta: "Os feiticeiros formigam no Rio, espalhados por toda a cidade, do cais à estrada de Santa Cruz", ${ }^{92}$ indicando práticas que se estendiam para além da então Capital Federal. Entre os "feiticeiros", João do Rio destaca "o Higino e o Breves, dois famosos tipos de Niterói, cuja crônica é sinistra", ${ }^{93}$ presenças no outro lado da baía de Guanabara às quais se soma João Gambá, que desenvolvia suas práticas religiosas desde 1910 e fundou o Ilê Asé Baba Olwô Omin, em Pendotiba, em 1938. ${ }^{94}$

As diferentes regiões da cidade estavam conectadas não só porque os religiosos transitavam por ruas e casas as mais diversas, mas, também, devido a necessidades intrínsecas aos seus rituais. Falando do sacrifício - "algumas partes (do animal sacrificado) são levadas para onde o santo diz" -, relatando a feitura de um babalaô - "coloca-se tudo num alguidar para jogar onde o opelê disser, no mar, num lago, em qualquer rio" -, ou ao citar Sanin - "fizemos outro dia um despacho no Campo de Santana" -, 95 João do Rio dá a conhecer como essas práticas eram efetuadas nos mais diversos lugares, muitas vezes em pontos cruciais da cidade. Em outra passagem oferece mais detalhes, com localizações específicas da difusão espacial desses ritos religiosos, por meio dos quais também se pode pensar os constrangimentos derivados da complexa urbanidade:

O babaloxá pergunta ao santo para onde deve ir o cabelo que vai cortar à futura filha e, depois de ardente meditação, indica com aparato a ordem divina. Essas descobertas são fatalmente as mesmas no centro de uma cidade populosa como a nossa. Se o santo é a mãe-d'água doce, Oxum, o cabelo vai para a Tijuca, a fábrica das Chitas; se é Iemanjá, fica na praia do Russel, em Santa Luzia; se é outro santo qualquer, basta um trecho de praça em que as ruas se cruzem. ${ }^{96}$

Tanto as referências ao mar, a lagos e rios, quanto algumas exigências rituais implicavam conexões com áreas além da urbe. Isso aparece em um relato de João do Rio acerca de um trabalho feito com a pretensão de causar a morte de alguém, no caso, de um presidente da república: "Os trabalhos dessa espécie fazem-se na roça, com orações e grandes matanças. Precisa a gente passar noites e noites a fio diante do fogareiro, 
com o teçubá na mão, a rezar". Em outra passagem, na qual comenta os elementos de que se compõem os feitiços, João do Rio cita "ervas arrancadas ao campo depois de lá deixar dinheiro para o saci", ${ }^{97}$ apresentando evidências dos vínculos dessas práticas religiosas com as matas, entre outros sítios naturais.

Entretanto, não se deve considerar que essas práticas e comunidades estivessem uniformemente distribuídas pela cidade. Ao contrário, difusão e concentração se complementavam. Pode-se dizer que, apesar de se fazerem presentes em toda a cidade, havia regiões da mesma que concentravam um número maior de comunidades religiosas com matrizes africanas.

As diversas referências aqui reunidas também permitem pensar como variou a concentração espacial dessas comunidades ao longo do tempo. O relato de Agenor Miranda Rocha sobre a continuidade das "quatro primeiras casas" faz pensar na questão das mudanças dessas comunidades, transferindo o polo de maior concentração das mesmas dentro da cidade e para outras regiôes do Estado. Neste sentido, ele defende que o fechamento das comunidades levou

à dispersão das pessoas iniciadas em cada uma delas. Esse processo de dispersão foi acompanhado pela abertura de novas casas, em moldes bem diferentes dos padrões até então encontrados. As novas lideranças religiosas emergentes na cidade deixam os bairros urbanos pobres e se deslocam para o subúrbio, onde instalam suas "roças". 98

A trajetória de mudança da Pequena África para a zona Norte, o subúrbio e a Baixada Fluminense é exatamente a da comunidade iniciada por Mãe Aninha, o Axé Opô Afonjá do Rio de Janeiro que, da Saúde, na década de 1880, teria passado, de acordo com variadas fontes e interpretaçoes, por diversos bairros da cidade do Rio de Janeiro - Santo Cristo, Gamboa, Rocha, Cavalcanti, Aldeia Campista e São Cristóvão - até chegar a Coelho da Rocha, na Baixada Fluminense, nos anos 40 (1944 ou 46), onde está até hoje. ${ }^{99}$

Outra comunidade que se deslocou dentro da Pequena África é a de Tia Ciata. Em um depoimento de Donga e através da análise de Roberto Moura, é possível recuperar a sua trajetória: chegada da Bahia, ela morou primeiro na Rua General Câmara; depois com, ou próximo a Miguel Pequeno, "uma espécie de cônsul dos baianos", "na Rua da Alfândega, 304"; em seguida, na Rua dos Cajueiros e, finalmente, na Rua Visconde de Itaúna, na Praça Onze. ${ }^{100}$ Essas mudanças são compreensíveis devido às dificuldades de subsistência dessas comunidades, em função da crescente especulação imobiliária na regiāo central da cidade, bem como das dinâmicas próprias às relações desses grupos religiosos e às vidas pessoais de seus integrantes.

De certo modo, também era previsível que as comunidades herdeiras daquelas criadas inicialmente, na Pequena África, ou não, germinassem em outras partes da cidade, uma vez que os cultos não eram restritos a africanos, baianos ou negros, e a expansão do axé é intrínseca ao ideário religioso afro-brasileiro. Falando de lideranças religiosas instaladas nos bairros centrais - João Alabá, Abedé, Guaiaku e Rozena - Agenor Miranda Rocha comenta que "sua influência alcançava bairros distantes, de onde provinham numerosos filhos, embriōes de futuras novas casas que, mais tarde, seriam abertas nos subúrbios cariocas". ${ }^{101}$

Entretanto, é preciso lembrar que essas comunidades enfrentavam constantes pressões externas, o que resultou, também, em razões para essas transferências. As reformas urbanas realizadas na área central da cidade, no início do século XX, com vistas ao saneamento, à modernização e à especulação imobiliária, também constituíram um fator importante para esses deslocamentos. Conforme esclarece Roberto Moura:

A Saúde, onde se concentrava grande parte da colônia baiana, (...) seria também afetada pelas reformas, fazendo com que muitos (...) fossem procurar moradia pelas ruas da Cidade Nova, além do Campo de Santana, ou para os subúrbios e, logo depois, nos morros em torno do Centro. ${ }^{102}$

Pode-se argumentar, também, que as regiōes que concentravam um número maior de comunidades religiosas com matrizes africanas eram, geralmente, de acordo com Agenor Miranda Rocha, "os bairros urbanos pobres". ${ }^{103}$ A Pequena África era um "polo de atração de população pobre”, no dizer do mesmo 
autor, fosse a zona portuária, fosse a Cidade Nova, regiōes periféricas em relação aos centros da cidade: o campo de Santana, no período imperial, e a praça Floriano, no período republicano. ${ }^{104}$ Quando João do Rio narra que foi "pela rua estreita com a visão sinistra da pobre mártir aos pulos, dessa cabeça pintada, entre os chocalhos e os atabaques, que dançava e gritava horrendamente...", ${ }^{105}$ a menção à rua estreita, embora seja válida para muitas das vias urbanas antigas e ainda existentes no Rio de Janeiro, pode ser contraposta à espacialidade das novas avenidas e outros logradouros projetados para a Capital da República no início do século XX.

O deslocamento dessas comunidades "para o subúrbio" também foi um movimento marcado pelas dificuldades econômicas. O mesmo vale para a ocupação da Baixada Fluminense e, mais recentemente, da zona Oeste da cidade. A presença das comunidades religiosas afro-brasileiras na Pequena África (zona portuária e Cidade Nova), em morros, nos subúrbios, na Baixada Fluminense e na zona Oeste indica a ocupação da periferia devido a processos de exclusão dessa população, bem como de seus valores e práticas, das regióes centrais e mais valorizadas da cidade. Como sintetizou Manuel Bandeira, em um verso do poema Mangue, de seu livro Libertinagem: "Houve tempo em que a Cidade Nova era mais subúrbio do que todas as Meritis da Baixada”. ${ }^{106}$

\subsection{Tipologias espaciais das comunidades de candomblé}

Ao longo do tempo não se observam apenas mudanças quanto à localização dessas comunidades na cidade do Rio de Janeiro e no estado fluminense. É importante perceber as transformaçôes processadas na estruturação física das mesmas, associadas a variações em sua designação. Muitas vezes essas comunidades são denominadas como terreiros, uma nomeação compartilhada com outras situações urbanas e arquitetônicas no Brasil. Nas memórias, depoimentos, relatos e reflexões até aqui recuperados, encontra-se outras denominações, casa e roça. A variação no uso desses termos indica transformações significativas quanto às possibilidades espaciais e às práticas dessas comunidades religiosas, bem como as assinala na passagem do tempo.

\subsubsection{Comunidades como casas}

Inicialmente, parece que havia apenas casas. Embora defenda que "toda essa gente vive bem, à farta" e, ao descrever a casa de Ojô, diga que "os móveis consertados indicavam que Ojô vive bem”, ${ }^{107}$ João do Rio não deixa de externar seu preconceito com relação às condições de salubridade de suas habitaçóes: "os transeuntes honestos, que passeiam na rua com indiferença, não imaginam sequer as cenas de Salpetrière africana passadas por trás de rótulas sujas"; "os feiticeiros (...) moram em casinholas sórdidas"; "para obter o segredo do feitiço, fui a essas casas, estive nas salas sujas"; qualifica como "casinhola suja e mal-cheirosa" a casa na qual presenciou uma cerimônia de egungum; e, contraditoriamente, diz que a casa de Ojô tem "um aspecto pobre e um cheiro desagradável". ${ }^{108}$ Uma descrição mais longa merece ser transcrita:

As casas dos minas (...) São quase sempre rótulas lôbregas, onde vivem com o personagem principal cinco, seis ou mais pessoas. Nas salas, móveis quebrados e sujos, esteirinhas, bancos; por cima das mesas, terrinas, pucarinhos de água, chapéus de palha, ervas, pastas de oleado onde se guarda o opelé, nas paredes, atabaques, vestuários esquisitos, vidros; e no quintal, quase sempre jabutis, galinhas pretas, galos e cabritos. ${ }^{109}$

Do relato de João do Rio, que pouco procura entender os modos de ser e viver do outro, emergem várias questóes relativas a essas comunidades, à estrutura física de que dispunham e alteravam com suas práticas cotidianas e excepcionais. Primeiro, o sentido comunitário, com vários habitantes reunidos em torno de uma liderança. Depois, as condições de salubridade estabelecidas em função do processo de marginalização social. $\mathrm{O}$ uso das rótulas como recurso para garantir privacidade e proteção a seus moradores, visitantes e acontecimentos. A convivência com animais para usos religiosos e comerciais. A elaboração de uma cultura material particular. E uma estruturação espacial específica na qual, a par- 
tir da distinção entre a rua e a casa, esta última era dividida em duas partes principais, sendo a primeira composta pelos recintos internos e a segunda pelo quintal, mas ambas se prestando a múltiplos usos que as conectavam.

Aparentemente, todos os poucos e pequenos recintos que compunham essas casas eram usados nas funções religiosas, em especial as salas e as camarinhas. João do Rio relata que "os pais-de-santo trabalham dia e noite nas camarinhas ou fazendo evocações diante dos fogareiros". ${ }^{110}$ Além disso, deve ser destacado o peji, ainda conforme a narrativa do mesmo autor: "o estado-maior é a coleção de terrinas e sopeiras colocadas numa espécie de prateleiras de bazar". ${ }^{111}$ Complementares aos espaços internos, os quintais também são importantes, servindo tanto para a realização de alguns rituais quanto para a criação de animais para serem usados nos rituais e comercializados, conforme outras referências de João do Rio: "Eu olhava a réstia estreita do quintal onde dormiam jabutis"; "os pais-de-santo são obrigados pela sua qualidade a fazer criação de bichos para vender e tê-los sempre à disposição quando precisam de sacrifício". ${ }^{112}$

Falando das tias baianas, Roberto Moura informa que mantinham "festas realizadas em homenagem aos santos que depois se profanizavam em encontros de música e conversa” ${ }^{113}$ Ele também relata que Tia Ciata, a mais famosa dessas tias, "não deixava de comemorar as festas dos orixás em sua casa da praça Onze, quando depois da cerimônia religiosa, frequentemente antecedida pela missa cristã assistida na igreja, se armava o pagode". ${ }^{114}$ De acordo com outros depoimentos e análises, havia localização específica para essa sucessão de eventos, pois, além da missa na igreja, as cerimônias religiosas e as festas nas casas tinham espaços claramente determinados em suas dinâmicas. Comentando as festas que Tia Ciata fazia "para os sobrinhos dela se divertirem", João da Baiana diz que "a festa era assim: baile na sala de visitas, samba de partido alto nos fundos da casa e batucada no terreiro". Pixinguinha faz comentário semelhante: "numa festa de preto havia o baile mais civilizado na sala de visitas, o samba na sala dos fundos e a batucada no terreiro". ${ }^{115}$ Nesse sentido, vale citar a análise da casa de Dona Esther, em Oswaldo Cruz, feita por Muniz Sodré: "era notável por sua extensão e pela frequência. Esta casa funcionava de maneira parecida com a da famosa Tia Ciata: na frente a 'brincadeira' (jogos de dança e música); nos fundos, cerimônias de culto aos orixás". ${ }^{116}$ De acordo com Candeia, que também considerava a casa de Dona Esther como um dos "pontos marcantes" de Oswaldo Cruz, ela "tinha o seu lado místico, entretanto não era candomblé", deixando a dúvida sobre o tipo de religiosidade por ela praticada, mas confirmando a variedade de usos dos espaços. ${ }^{117}$

Essa estruturação por setores está associada às dinâmicas de suas atividades cotidianas, religiosas, festivas e artísticas, com suas características mais privadas ou públicas. De acordo com os relatos, pode-se dizer que as festas eram mais abertas ao público, com a casa tornando-se, temporariamente, quase uma rua, embora não totalmente pública. Já as cerimônias religiosas eram mais privadas. Roberto Moura defende que os candomblés "eram mais fechados à curiosidade de estranhos". ${ }^{118}$ Não se tratava da determinação de áreas estanques e exclusivas. Ao contrário, os setores se estruturavam pelo uso, pelos acontecimentos cotidianos e excepcionais, nos diferentes rituais e festas.

Para Muniz Sodré, esse "modelo de funcionamento (...) simboliza a estratégia de resistência pelo jogo à marginalização imposta ao negro em seguida à Abolição". Em outra passagem de $O$ terreiro e a cidade, o mesmo autor sublinha a dimensão política desse modelo:

A economia semiótica da casa, isto é, seus dispositivos e táticas de funcionamento, fazia dele um campo dinâmico de reelaboração de elementos da tradição cultural africana, gerador de significados capazes de dar forma a um novo modo de penetração urbana para os contingentes negros. ${ }^{119}$

Em seu livro sobre Tia Ciata, Roberto Moura apresenta a planta baixa da casa onde residia, "conforme depoimento dos parentes que lá conviveram”. Além de exibir um desenho (Anexo 1), ele faz uma descrição: 
Depois de uma sala de visitas ampla, onde nos dias de festa ficava o baile, a casa se encompridava para o fundo, num corredor escuro onde se enfileiravam três quartos grandes intervalados por uma pequena área por onde entrava luz, através de uma claraboia. No final, uma sala de refeições, a cozinha grande, e a despensa. Atrás da casa, um quintal com um centro de terra batida para se dançar e depois um barracão de madeira onde ficavam ritualmente dispostas as coisas do culto. ${ }^{120}$

Embora tenha sido produzido a partir do depoimento, esse desenho é incompleto, um tanto contraditório em relação à sua fonte e esquemático, o que obriga a tomá-lo como expressão visual de lembranças e ideias espaciais de outros. Apesar disto, é possível com o desenho, a descrição, os depoimentos e as interpretaçóes caracterizar um tipo urbano-arquitetônico. Esse desenho pode, portanto, ser relacionado às tipologias urbanas e arquitetônicas do Brasil à época e mesmo a momentos antecedentes. A casa poderia ser aproximada do tipo das "residências menores" do período compreendido entre 1850 e 1900, de acordo com o Quadro geral da arquitetura no Brasil, traçado por Nestor Goulart dos Reis Filho, pois tinha um poço de iluminação, o vão com claraboia que dividia a "sala de visitas" do "quarto sinhá Assiata". Entretanto, também tinha uma alcova, o "quarto sinhá velha", o que a vincula ao tipo dominante das residências construídas no Brasil no período da colonização portuguesa, nas quais, "aproveitando antigas tradições urbanísticas de Portugal, nossas vilas e cidades apresentavam ruas de aspecto uniforme, com residências construídas sobre o alinhamento das vias públicas e paredes laterais sobre os limites dos terrenos". ${ }^{121}$ Sem recuos, jardins, porôes e outros recursos que permitissem melhor iluminação e aeração dos cômodos, à exceção da "pequena área por onde entrava luz, através de uma claraboia", essa casa pouco incorporava as novidades introduzidas na arquitetura durante o Oitocentos, com vistas à maior salubridade das habitações.

Um trecho da reportagem de João do Rio permite pensar como esses espaços eram reestruturados por pessoas e coisas durante a realização das cerimônias religiosas, ao descrever uma delas:

Quando chegamos, a sala estava enfeitada. Em derredor sentavam-se muitos negros e negras mastigando olobó, ou cola amargosa, com as roupas lavadas e as faces reluzentes. A um canto, os músicos, fisionomias estranhas, faziam soar, com sacolejos compassados, o xequerê, os atabaques e ubatás, com movimentos de braços desvairadamente regulares. Não se respirava bem. (...) Olhei o célebre pai-de-santo, cujas filhas são sem conta. Estava sentado à porta da camarinha. ${ }^{122}$

Pode-se concluir que essas limitações urbanas e arquitetônicas não impediam que essas construções fossem reinventadas cotidianamente, de acordo com diferentes usos. O que determina uma tipologia espacial e edilícia pouco morfológica, pois mesmo algumas formas a princípio indispensáveis aos rituais podem ser relativizadas e transformadas pelos usos. Assim, indica uma tipologia mais estrutural, na qual importam mais as relações entre espaços, construçôes, coisas, seres e açôes.

Recuperando um comentário de Agenor Miranda Rocha sobre a trajetória de Mãe Aninha no Rio de Janeiro - "Aninha não tinha nenhum terreiro no Rio de Janeiro, mas tinha axê"-, Muniz Sodré explica: "Isto quer dizer que a força produzia o espaço necessário à sua atividade". E complementa: "O terreiro definia-se, assim, não por sua territorialidade física, mas enquanto centro de atividades litúrgicas e polo irradiador de força”. ${ }^{123} \mathrm{O}$ que faz pensar na crítica de Aldo van Eyck à espacialidade racional e funcionalista do movimento moderno de arquitetura, diferenciando espaço de lugar, com o primeiro sendo abstrato, concebido mentalmente, e o segundo, vivido, experimentado pelo corpo. Diferença que Michel de Certeau mantém, de certo modo, embora invertendo os termos: lugar sendo "a ordem (seja qual for) segundo a qual se distribuem elementos nas relações de coexistência” - o que "implica uma indicação de estabilidade" -, enquanto espaço "é um cruzamento de móveis"; "em suma", de acordo com Certeau, "o espaço é um lugar praticado". ${ }^{124}$ Esta inversão permite constatar como, mais do que a designação, o que importa é reconhecer a plasticidade dinâmica, inventiva e regeneradora produzida pelo axé (simplificadamente, força físico-espiritual) nas comunidades de candomblé. 


\subsubsection{Comunidades como roças}

Um dos capítulos do livro de Agenor Miranda Rocha, "Estrutura e organização de uma casa de Kêtu", expõe "a organização e a distribuição espacial de uma casa-de-santo", através de um desenho de Carlos de Oguyã, datado de 1993 (Anexo 2), cuja legenda informa a "disposição hipotética de um terreiro", e de uma apresentação textual da "distribuição do espaço físico e ritual". ${ }^{125}$

O terreiro aí apresentado é bem diferente das casas nas quais funcionavam as comunidades de candomblé no final do século XIX e início do século XX. A princípio, é semelhante às roças no subúrbio da cidade, mas, como o próprio autor diferencia, são "roças estruturadas". Muniz Sodré define roça como um "termo baiano, sinônimo de terreiro de candomblé". ${ }^{126}$ A constituição das comunidades de candomblé como roças é um dos fatores que marcam a história das mesmas no Rio de Janeiro, segundo Agenor Miranda Rocha, pois, como visto, ele aponta o surgimento dessas roças como um dos dados a marcar o segundo momento de sua cronologia. ${ }^{127}$ Sobre esse deslocamento das comunidades de candomblé da região central da cidade para o subúrbio e a Baixada Fluminense, com a consequente transformação das casas em roças, José Flávio Pessoa de Barros defende que

uma vez que o processo de constituição e implementação dos Terreiros de candomblé supõe, ao mesmo tempo, a urbe - espaço construído -, e a floresta - espaço-mato -, o deslocamento imposto, se trouxe algumas dificuldades e problemas, também favoreceu o estreito relacionamento dessas duas dimensões tão importantes no imaginário religioso do povo-de-santo. O espaço-mato tornando-se mais evidente e próximo, reforçou os laços entre o homem e a natureza, ao mesmo tempo em que circunscrevia o grupo religioso e o protegia da curiosidade dos não-adeptos. ${ }^{128}$

A apresentação textual de Agenor Miranda Rocha ajuda a compreender o que, no desenho de Carlos de Oguyã, pode passar despercebido. Ele expõe com clareza como as comunidades de Kêtu são estruturadas, apresentando seus principais setores:

De maneira geral, as roças são compostas por dois espaços bem definidos: a área construída e o terreiro. $\mathrm{Na}$ área construída, existem ambientes públicos (sala, barracão, banheiros etc.) e privados (quartos-de-santo, camarinha, quarto de malas etc.). Existe ainda um terceiro espaço, não edificado, que, de forma mais ou menos imaginária, representa a 'mata. ${ }^{129}$

E apresenta a composição de cada um dos setores, dos espaços mais públicos aos mais reservados. Explica as possibilidades de conhecimento e uso dos espaços por diferentes pessoas: "de acordo com o grau de entronização, as pessoas transitam pelo espaço que vai do portão ao mato, tendo boa margem de consciência sobre onde podem ou não estar, e quando". Assim, torna evidente como o tempo é um fator importante na dinâmica dessas comunidades, como os espaços se caracterizam também em função do quê e quando neles acontece. Demonstra como os espaços admitem certa reversibilidade: "a distribuição do espaço varia de uma casa para outra e até dentro de uma mesma casa, onde a disposição dos espaços públicos e privados pode ser alterada de acordo com a ocasiáo". E marca os polos da relação entre espaços públicos e privados no terreiro: "O espaço público por excelência é o barracão, onde se realizam as festas"; "em algum local distante do acesso público, encontramos também o ilê axé, o quarto onde as yaôs são recolhidas por ocasião das obrigaçōes”. ${ }^{130}$

Sobre os quartos-de-santo, Agenor Miranda Rocha explica que "cada orixá tem a sua própria casa, o quarto, onde é cuidado e alimentado". Quanto à disposição espacial dessas casas ou quartos na comunidade, embora o desenho de Carlos de Oguyã apresente o terreiro "tendo ao centro o barracão e à sua volta os quartos de orixá", é preciso lembrar que o mesmo é uma "disposição hipotética de um terreiro", conforme a legenda. ${ }^{131}$ Os comentários do autor sugerem múltiplas possibilidades plásticas, além daquela apresentada graficamente, a partir de alguns princípios por ele também indicados. Ao dizer que os quartos "ocupam uma disposição determinada no espaço da Roça, de acordo com o tipo de Orixá", ele deixa entrever a conexão entre os espaços mítico e físico, a relação existente entre a posição do orixá 
na cosmogonia e a situação de sua casa no terreiro. Ele também dá indicações de como o terreiro é estruturado por espaços externos e internos que demarcam setores que também estão diretamente vinculados à cosmogonia.

Com relação à parte externa, ele explicita a primazia obrigatória de Exu e de sua casa na disposição espacial, geralmente junto ao portão ou à porta, ao dizer que, "na chegada, começa-se salvando Exu e, em seguida, passando pela casa de cada Orixá, salvando cada um e comunicando sua chegada”. E dá informações sobre alguns outros espaços externos:

finalmente, às vezes bem disfarçada, no meio do mato, vemos uma pequena casa branca, onde apenas pessoas especialmente designadas podem entrar, e onde, mesmo os membros da casa, quando se aproximam, o fazem abaixados, em sinal de respeito: é o ilê ibó aku, a casa dos mortos, ancestrais do terreiro. ${ }^{132}$

Segundo ele, "na parte interna, geralmente dentro da casa, vamos encontrar as casas dos Orixás que nos itans são considerados moradores de palácios, situados nas cidades africanas. São eles Oxalá (palácio de Ifé), Xangô (palácio de Oyó), e as Yabás”. Esse comentário indica como construçôes e áreas livres aludem a paisagens africanas, com seus palácios, casas, cidades, territórios, tornando explícita a relação entre espaços históricos na África e espaços físicos das comunidades de candomblé e permitindo perceber outras dimensões simbólicas do terreiro - conjunto de espaços, construções, coisas e seres mais complexo estruturalmente do que pode parecer aos leigos.

Sem especificar muito mais, suas indicações sobre os quartos-de-santo deixam subentendido que as demais casas de orixás se localizam na parte exterior, situando-se entre o portão e a mata. Ao não especificar onde os quartos-de-santo não mencionados devem estar, ele não quer dizer que os mesmos podem estar em qualquer lugar. Ao contrário, o seu silêncio indica que o conhecimento se dá na vivência religiosa, além de reafirmar o cunho estrutural da tipologia espacial dessas comunidades.

Ao dizer que parte do espaço não edificado "representa a 'mata" e que, nessa mata, "que rememora o passado africano, estão as folhas utilizadas nos rituais", o autor sugere dimensões utilitárias e simbólicas desse ambiente crucial para os ritos do candomblé. A floresta mítica sobrevive no espaço-mata, a porção de terra livre das diferentes comunidades de terreiro; lugar onde são cultivadas árvores, arbustos e ramagens, nas quais se busca as folhas necessárias ao dia-a-dia, entre outras práticas e rituais. Espaçomata que é configurado em cada comunidade de acordo com possibilidades espaciais e culturais. Agenor Miranda Rocha afirma que "muitas casas, devido à sua dimensão, não dispõem de espaço sequer para representar, de forma mais ou menos aproximada, essa mata, mas uma pessoa atenta sempre identificará seus elementos mínimos em qualquer casa”. ${ }^{133}$

$\mathrm{Na}$ exposição de Agenor Miranda Rocha, encontra-se uma afirmação que reitera a relação da comunidade de candomblé com outros locais da região, além do terreiro: "alguns preceitos exigem que se façam obrigações em mata verdadeira; nesse caso, deslocam-se para ela, onde são feitos os trabalhos". ${ }^{134}$ Desenvolvendo o que afirmamos antes, ${ }^{135}$ podemos sustentar que a floresta é o oposto complementar da cidade, o lugar de onde provêm caças e folhas, entre outros elementos fundamentais à vida. São, portanto, lugares onde se rememora o tempo antigo, quando os homens se aventuravam pela mata em busca dos alimentos necessários à sobrevivência. Lugares, também, onde pensar o presente - mata, folhas, caças e caçadores conectam o tempo mítico ao passado próximo, quando a vida urbana não parecia tão apartada do campo, e mesmo à atualidade, preservando sentidos nostálgicos, metafóricos e imediatos para os habitantes das metrópoles contemporâneas. Assim, essas religióes evidenciam alcance ambiental, transbordam dos espaços internos dos terreiros para o exterior, chegam às estradas, matas, cachoeiras e praias, passando pelas ruas das cidades brasileiras onde é grande e forte a presença dos afrodescendentes. 


\subsection{Casas e roças de candomblé como patrimônio cultural urbano}

As grandes e tradicionais comunidades de terreiro são amplos microcosmos dos universos culturais africanos preservados e reestruturados no Brasil; são espaços de resistência e atualização cotidiana da vida pretérita na África. E o são, não apenas as grandes e tradicionais comunidades: independentemente de suas dimensôes, que variam de acordo com as possibilidades existentes nos diferentes contextos, urbanizados ou ainda rurais, os terreiros representam a geografia típica de algumas regiōes africanas. Muitas vezes pequenos, modestos, apertados em terrenos exíguos de urbes densamente ocupadas, as comunidades - casas, ou terreiros - aludem com recursos mínimos à oposição complementar de cidade e campo, dentro e fora, Terra e Céu, vivos e mortos.

Suas construções - conjunto de casas, ou quartos; espaços cobertos e ao ar livre, que abrigam diferentes moradores e visitantes, do mundo terreno ou não - interessam não por configurarem um estilo arquitetônico, nem apenas por delinearam uma tipologia espacial (arquitetônica e paisagística) que é menos morfológica e mais estrutural. Interessam também como metáforas vivas de civilizaçôes, suas paisagens, cidades e imaginários, representando portôes, ruas, praças, monumentos, casas, palácios e espaços naturais, em meio aos quais são cultivadas dimensões espirituais da existência, assim como a sociabilidade pública. $\mathrm{O}$ que, de modo nada surpreendente, aproxima casas e roças, antigas e novas, grandes e pequenas comunidades de candomblé. E também indica como o arrefecer da marginalização que esses religiosos têm sofrido ao longo do tempo pode contribuir para aflorar publicamente a plasticidade dinâmica própria às comunidades de candomblé.

Ao comentar "o processo de constituição e implementação dos terreiros de candomblé" no Rio de Janeiro, nos anos 50, José Flávio Pessoa de Barros observa como eles se fazem legíveis, por meio de discretos signos urbanos que indicam a presença cotidiana dessas religiōes na cidade:

Os templos, embora inseridos no cenário arquitetônico urbano-periférico, podiam ser distinguidos - e ainda o são - através da presença de sinais diacríticos, como a bandeira de tempo (mastro fincado no solo, na entrada do terreno, onde tremula uma bandeira branca) e as quartinhas (potes de barro), colocadas sobre os muros e telhados. ${ }^{136}$

Inscrições em muros brancos, jarros, garrafas e potes sobre portadas, bandeiras brancas surgindo inesperadamente em meio a árvores, muros e fios de eletricidade, mais outras tantas coisas, constituem uma simbólica urbana particular. Em boa parte enigmáticos, aparentemente incompreensíveis, esses elementos sinalizam especificidades religiosas e culturais. São signos de resistência, de preservação de imaginários, ideias, saberes e valores. Coisas e práticas cujos significados dizem respeito não apenas aos membros dessas comunidades e àqueles que as frequentam, pois, inseridas na dinâmica social da cidade, do estado e do país, têm sentidos que vão além desses grupos religiosos, com alcance local, regional e nacional; o que sugere a possibilidade de sua preservação como patrimônio cultural carioca, fluminense, brasileiro.

Sobre as ações de preservação de comunidades religiosas afro-brasileiras no Rio de Janeiro como bens simbólicos da nação brasileira, pode-se observar inicialmente que esse processo poderia ter acontecido desde a década de 1980. Àquela altura, mais exatamente em 1986, o Iphan tombou o Ilê Axé Iyá Nassô Oká, o Terreiro da Casa Branca do Engenho Velho, em Salvador, na Bahia, de acordo com o processo $n^{\circ}$ 1067-T-82. Na mesma cidade, a instituição tombou o Ilê Axé Opô Afonjá, o Terreiro do Axé Opô Afonjá, em 2000, de acordo com o processo n 1432-T-98. Ambos os bens estão inscritos no Livro do Tombo Histórico e no Livro do Tombo Arqueológico, Etnográfico e Paisagístico. ${ }^{137}$

Entretanto, é um tanto compreensível a defasagem entre as ações de preservação de comunidades de candomblé na Bahia e no Rio de Janeiro. Diferentemente do que ocorreu em Salvador, nos anos 80, nenhuma das comunidades de candomblé do Rio de Janeiro solicitou alguma ação do Iphan ou de outro órgão de preservação cultural com vistas à sua preservação como patrimônio de valor nacional, regional ou local. Isto passou a ocorrer apenas na primeira década do século XXI. 
É fato também que, naquela mesma década, mais exatamente em 1984 - portanto, antes do tombamento do Terreiro da Casa Branca do Engenho Velho, em Salvador, pelo órgão federal de preservação do patrimônio cultural -, o Instituto Estadual de Patrimônio Cultural (Inepac), no Rio de Janeiro, tombou a Pedra do Sal, na capital do estado, por meio do processo E-18/300.048/84. Nas palavras de Ítalo Campofiorito, diretor do Inepac à época, a Pedra do Sal, como "monumento negro", devia ser tombada porque, "além de espaço ritual consagrado, é o mais antigo monumento que se pode vincular à história do samba carioca". ${ }^{138}$ Essa ação preservacionista pode ser vinculada à "tentativa de monumentalização da negritude" empreendida pela administração de Leonel Brizola no governo do Estado do Rio de Janeiro, entre 1983 e 1987, com a construção do Sambódromo, do monumento a Zumbi e da escola Tia Ciata, na região da antiga Praça Onze, de acordo com a interpretação de Mariza Soares. ${ }^{139}$ Com essas construções e o reconhecimento da Pedra do Sal como monumento, o poder público estadual reconstituía simbolicamente a Pequena África, que fora dizimada pelos processos excludentes de ocupação do território urbano pela especulação imobiliária.

Contudo, em verdade, é preciso observar que a ação pioneira de preservação cultural de valores religiosos afro-brasileiros no Brasil foi empreendida pelo Serviço de Patrimônio Histórico e Artístico Nacional, o Sphan (depois renomeado como Iphan), no segundo ano de funcionamento dessa instituição, em relação a comunidades do Rio de Janeiro. Em 1938, o Sphan tombou uma parte da coleção do Museu da Polícia Civil do Estado do Rio de Janeiro, constituída a partir de apreensões de objetos feitas em ações de repressão policial às práticas religiosas afro-brasileiras na então Capital Federal. Parte dessa coleção foi inscrita como bem $\mathrm{n}^{\circ} 001$ do Livro do Tombo Arqueológico, Etnográfico e Paisagistico, sob a alcunha de "Museu de Magia Negra: acervo", em 1938, de acordo com o processo n ${ }^{\circ}$ 0035-T38. ${ }^{140}$ No âmbito dos procedimentos de inclusão de comunidades religiosas afro-brasileiras no Rio de Janeiro como patrimônio cultural da nação, o Iphan pode pensar em mudar a designação desse bem no referido Livro do Tombo, com vistas a evitar a visão preconceituosa que deu origem a esse nome e com ele se propaga.

Esses tombamentos indicam um (lento) processo de revisão do valor das contribuições africanas para a constituição da cultura afro-brasileira. Com relação às comunidades de candomblé no Rio de Janeiro, é preciso que haja reconhecimento do valor como patrimônio cultural, com significância local, regional e nacional, de sua plasticidade muitas vezes singela, mas bastante complexa. Além de suas dimensões simbólicas, espaços, construções, objetos e seres recontam a história das comunidades de candomblé no Rio de Janeiro, das casas às roças.

\section{Notas}

${ }^{1}$ Este artigo resulta de uma primeira reflexão derivada de pesquisa e análise realizada como complemento ao mapeamento dos terreiros de candomblé do Estado do Rio de Janeiro, realizado para o Instituto do Patrimônio Histórico e Artístico Nacional (Iphan) por equipe coordenada por Márcia Ferreira Netto. Agradeço a leitura e os comentários que Guilherme Lemos, Márcia Ferreira Netto, Márcia Sant'Anna e Til Pestana fizeram do texto apresentado ao Iphan, e a colaboração de Aline dos Santos Almeida, bolsista de iniciação científica no Programa PIBIC da UERJ, na preparação deste artigo.

${ }^{2}$ RIO, João do. As religiões do Rio (1904). Rio de Janeiro: José Olympio, 2006. p. 15.

${ }^{3}$ ROCHA, Agenor Miranda. As naçôes Kêtu: origens, ritos e crenças. Os candomblés antigos do Rio de Janeiro. (1994). Rio de Janeiro: Mauad, 2000. p. 21.

${ }^{4}$ RIO, João do. Op. cit., p. 20.

${ }^{5}$ Idem, ibidem, p. 68, 78.

${ }^{6}$ Silva, Yara. Tia Carmem: negra tradição da Praça Onze. Rio de Janeiro: Garamond, 2009. p. 37.

${ }^{7}$ SODRÉ, Muniz; LIMA, Luiz Filipe. Um vento sagrado: história de vida de um adivinho da tradição nagô-kêtu brasileira. Rio de Janeiro: Mauad, 1996. p. 63.

${ }^{8}$ RIO, João do. Op. cit., p. 29.

9 PRANDI, Reginaldo. Modernidade com feitiçaria: candomblé e umbanda no Brasil do século XX. Tempo Social, São Paulo, USP, v. 2, n. $1,1^{\circ}$ sem. 1990. p. 50. 
${ }^{10}$ ALVES, Marcelo. As aventuras do homus cinematographicus (estrelando: João do Rio). DOMINGUES, Chirley; ALVES, Marcelo (Orgs.). A cidade escrita: literatura, jornalismo e modernidade em João do Rio. Op. cit., p. 96.

${ }^{11}$ VILHENA, Luís Rodolfo. A Babel da crença: o campo religioso carioca em João do Rio. In: Ensaios de antropologia. Rio de Janeiro: EdUerj, 1997. p. 115.

${ }^{12}$ ROCHA, Agenor Miranda. Op. cit., p. 18.

${ }^{13}$ RIO, João do. Op. cit., p. 55.

${ }^{14}$ Idem, ibidem, p. 86-87.

${ }^{15}$ Apud SODRÉ e LIMA. Op. cit., p. 56.

${ }^{16}$ Apud ARAÚJO, Ari. Entrevista com Agenor Miranda. Revista do Patrimônio Histórico e Artístico Nacional, Rio de Janeiro, IPHAN, n. 25, 1997. p. 212.

${ }^{17}$ Apud MOURA, Roberto. Tia Ciata e a Pequena África no Rio de Janeiro. Rio de Janeiro: Secretaria Municipal de Cultura, Departamento Geral de Documentação e Informação Cultural, Divisão de Editoração, 1995. p. 43.

${ }^{18}$ Idem, ibidem, p. 98.

${ }^{19}$ SODRÉ, Muniz. O terreiro e a cidade. A forma social negro-brasileira. Salvador: Secretaria da Cultura e Turismo; Imago, 2002. p. 149.

${ }^{20}$ NETTO, Márcia Ferreira (Org.). Mapeamento dos terreiros de candomblé do Estado do Rio de Janeiro. Rio de Janeiro: IPHAN, 2010. CD-ROM

${ }^{21}$ RIO, João do. Op. cit., p. 15, 51-52, 61, 81.

${ }^{22}$ MAGGIE, Yvonne. Medo do feitiço: relaçōes entre magia e poder no Brasil. Rio de Janeiro: Arquivo Nacional, 1992. p. 276-277.

${ }^{23}$ MOURA, Roberto. Op. cit., p. 95.

${ }^{24}$ RIO, João do. Op. cit., p. 29.

${ }^{25}$ MOURA, Roberto. Op. cit., p. 86.

${ }^{26}$ ROCHA, Agenor Miranda. Op. cit., p. 23.

${ }_{27}$ GOMES, Tiago de Melo. Para além da casa de Tia Ciata: outras experiências no universo cultural carioca, 1830-1930. Afro-Ásia, Salvador, UFBA, v. 29-30, 2003. p. 179.

${ }^{28}$ Idem, ibidem, p. 198.

${ }^{29}$ ROCHA, Agenor Miranda. Op. cit., p. 26-27.

${ }^{30}$ RIO, João do. Op. cit., p. 20.

${ }^{31}$ Idem, ibidem.

${ }^{32}$ Idem, ibidem, p. 35.

${ }^{33}$ MOURA, Roberto. Op. cit., p. 93.

${ }^{34}$ ROCHA, Agenor Miranda. Op. cit., p. 25.

${ }^{35}$ Apud ARAÚJO, Ari. Op. cit., p. 214.

${ }^{36}$ Apud NETTO, Márcia Ferreira. Op. cit.

${ }^{37}$ ROCHA, Agenor Miranda. Op. cit., p. 24.

${ }^{38}$ ALVAREZ, Marcos César; Fernando Afonso Salla; Luís Antônio F de Souza. A sociedade e a Lei: o Código Penal de 1890 e as novas tendências penais na primeira República. Justiça e História, Porto Alegre, v. 3, n. 6, 2003.

${ }^{39}$ ROCHA, Agenor Miranda. Op. cit., p. 23-26.

${ }^{40}$ BARROS, José Flávio Pessoa de. O banquete do rei... Olubajé: uma introdução à música afro-brasileira. Rio de Janeiro: Ao Livro Técnico, 2000. p. 31.

${ }^{41}$ Idem, ibidem, p. 35.

42 Apud MARRA, Heloísa. Pai de todos. In: O Globo, Rio de Janeiro, 28/08/2004, Caderno Ela, p. 7.

${ }^{43}$ Disponível em <http://pt.wikipedia.org/wiki/Bate_-_Folha_Rio_(Kupapa_Unsaba)>. Acesso em 01/06/2010.

${ }^{44}$ NETTO, Márcia Ferreira. Op. cit.

${ }^{45}$ ROCHA, Agenor Miranda. Op. cit., p. 26.

${ }^{46}$ MOURA, Roberto. Op. cit., p. 106.

${ }^{47}$ ROCHA, Agenor Miranda. Op. cit., p. 25.

${ }^{48}$ REBOUÇAS FILHO, Diógenes. Pai Agenor. Salvador: Corrupio, 1998. p. 78-79. 
${ }^{49}$ PARES, Luiz Nicolau. Nota 6 do texto de apresentação. In: TOBIOBÁ, João Batista dos Santos. 21 cartas e um telegrama de Mãe Aninha a suas filhas Agripina e Filhinha, 1935-1937. Afro-Asia, Salvador, UFBA, v. 36, 2007. p. 268.

${ }^{50}$ TOBIOBÁ, João Batista dos Santos. Ibidem.

${ }^{51}$ ROCHA, Agenor Miranda. Op. cit., p. 25-27; Iyá Davina. Disponível em <http://pt.wikipedia.org/wiki/Iy\%C3\%A1_ Davina $>$. Acesso em 01/06/2010; SILVA, Yara. Op. cit., p. 44.

${ }^{52}$ NETTO, Márcia Ferreira. Op. cit.

${ }^{53}$ Idem, ibidem;

${ }^{54}$ ROCHA, Agenor Miranda. Op. cit., p. 26.

${ }^{55}$ BARROS, José Flávio Pessoa de. Op. cit., p. 33-34.

${ }^{56}$ Idem, ibidem, p. 33.

${ }^{57}$ NETTO, Márcia Ferreira. Op. cit.

${ }^{58} \mathrm{Ver}<\mathrm{http}: / /$ axetumbajunsara.blogspot.com>. Acesso em 02/06/2010.

${ }^{59}$ ROCHA, Agenor Miranda. Op. cit., p. 26.

${ }^{60}$ BARROS, José Flávio Pessoa de. Op. cit., p. 31.

${ }^{61}$ Idem, ibidem, p. 32.

${ }^{62}$ FERNANDES, Nilo; FERNANDES, Elizabeth; VIDAL, Marcelo (Orgs.). Pai Zezito d'Oxum. A chegada da nação Ijexá no Rio de Janeiro. Rio de Janeiro: s.e., 2005. p. 19, 24.

${ }^{63}$ BARROS, José Flávio Pessoa de. Op. cit., p. 34.

${ }^{64}$ Idem, ibidem, p. 33-35.

${ }^{65}$ COSSARD, Gisèle Omindarewá. Awó: o mistério dos orixás. Rio de Janeiro: Pallas, 2006. p. 206.

${ }^{66}$ NETTO, Márcia Ferreira. Op. cit.

${ }^{67}$ BARROS, José Flávio Pessoa de. Op. cit., p. 31-32.

${ }^{68}$ PRANDI, Reginaldo. Linhagem e Legitimidade no candomblé paulista. Revista Brasileira de Ciências Sociais, São Paulo, ANPOCS, n. 14, 1990. p. 18-31. Disponível em <http://www.anpocs.org.br/portal/publicacoes/rbcs_00_14/rbcs14_02. htm>. Acesso em 12 de junho de 2010.

${ }^{69}$ BARROS, José Flávio Pessoa de. Op. cit., p. 35.

${ }^{70}$ RIO, João do. Op. cit., p. 29.

${ }^{71}$ Idem, ibidem, p. 43-44.

${ }^{72}$ Idem, ibidem, p. 61.

${ }^{73}$ Apud MOURA, Roberto. Op. cit., p. 97.

${ }^{74}$ RIO, João do. Op. cit., p. 38.

${ }^{75}$ Idem, ibidem, p. 19-20.

${ }^{76}$ ROCHA, Agenor Miranda. Op. cit., p. 23-24.

${ }_{77}^{7 I O}$, João do. Op. cit., p. 44, 50, 51-52, 64-66, 80, 82-83.

${ }^{78}$ Apud ARAÚJO, Ari. Op. cit., p. 211.

${ }^{79}$ ROCHA, Agenor Miranda. Op. cit., p. 25.

${ }^{80}$ MOURA, Roberto. Op. cit., p. 134.

${ }^{81}$ Idem, ibidem, p. 93.

${ }^{82}$ Cf. LÍRIO, Alba (org.) Heitor dos Prazeres: sua arte e seu tempo. Rio de Janeiro: ND Comunicação, 2003, p. 47.

${ }^{83}$ TOBIOBÁ, João Batista dos Santos. Op. cit., p. 268.

${ }^{84}$ Apud NETTO, Márcia Ferreira. Op. cit.

${ }^{85}$ RIO, João do. Op. cit., p. 63.

${ }^{86}$ MAGGIE, Yvonne. Op. cit., p. 276-277.

${ }^{87}$ SODRÉ, Muniz. Op. cit., p. 150.

${ }^{88}$ Apud ARAÚJO, Ari. Op. cit., p. 214.

${ }^{89}$ SODRÉ, Muniz. Op. cit., p. 149.

${ }^{90}$ GOMES, Tiago de Melo. Op. cit., p. 195.

${ }^{91}$ RIO, João do. Op. cit., p. 50. 
${ }^{92}$ Idem, ibidem, p. 51.

${ }^{93}$ Idem, ibidem, p. 51-52.

${ }^{94}$ NETTO, Márcia Ferreira. Op. cit.

${ }^{95}$ RIO, João do. Op. cit., p. 32, 79, 86.

${ }^{96}$ Idem, ibidem, p. 41.

${ }^{97}$ Idem, ibidem, p. 56, 59.

${ }_{98}^{8}$ ROCHA, Agenor Miranda. Op. cit., p. 26.

${ }^{99}$ REBOUÇAS FILHO, Diógenes. Op. cit., p. 78; ROCHA, Agenor Miranda. Op. cit., p. 19; BARROS, José Flávio Pessoa de. Op. cit., p. 31; TOBIABÁ, João Batista dos Santos. Op. cit., p. 270; NETTO, Márcia Ferreira. Op. cit.

${ }^{100}$ Apud MOURA, Roberto. Op. cit., p. 96, 105.

${ }^{101}$ ROCHA, Agenor Miranda. Op. cit., p. 24.

${ }^{102}$ MOURA, Roberto. Op. cit., p. 55.

${ }^{103}$ ROCHA, Agenor Miranda. Op. cit., p. 26.

${ }^{104}$ Sobre a questão da centralidade no Rio de Janeiro, ver SISSON, Rachel. Marcos históricos e configuraçôes espaciais. Um estudo de caso: os centros do Rio de Janeiro. Arquitetura Revista, Rio de Janeiro, FAU-UFRJ, v. 4, 2/ sem. 1986. p. 56-81. ${ }^{105}$ RIO, João do. Op. cit., p. 49.

${ }^{106}$ BANDEIRA, Manuel. Mangue. In: Libertinagem. Rio de Janeiro: Ed. do autor, 1930.

${ }^{107}$ RIO, João do. Op. cit., p. 52, 81.

${ }^{108}$ Idem, ibidem, p. 35, 52, 74, 80.

${ }^{109}$ Idem, ibidem, p. 29-30.

${ }^{110}$ Idem, ibidem, p. 31.

${ }^{111}$ Idem, ibidem, p. 42.

${ }^{112}$ Idem, ibidem, p. 32.

${ }^{113}$ MOURA, Roberto. Op. cit., p. 93.

${ }^{114}$ Idem, ibidem, p. 100.

${ }^{115}$ Apud MOURA, Roberto. Ibidem, p. 83.

${ }^{116}$ SODRÉ, Muniz. Op. cit., p. 149.

${ }^{117}$ Apud MOURA, Roberto M. No principio, era a roda: um estudo sobre samba, partido-alto e outros pagodes. Rio de Janeiro: Rocco, 2004. p. 140.

${ }^{118}$ MOURA, Roberto. Op. cit., p. 101.

${ }^{119}$ SODRÉ, Muniz. Op. cit., p. 149.

${ }^{120}$ MOURA, Roberto. Op. cit., p. 102.

${ }^{121}$ REIS FILHO, Nestor Goulart dos. Quadro geral da arquitetura no Brasil (1970). São Paulo: Perspectiva, 1983. p. 22 , 48.

${ }^{122}$ RIO, João do. Op. cit., p. 44-45.

${ }^{123}$ SODRÉ, Muniz. Op. cit., p. 104-105.

${ }^{124}$ Sobre o conceito de espaço na modernidade, ver FORTY, Adrian. Space. In: Words and buildings. A vocabulary of modern architecture. London: Thames \& Hudson, 2000, p. 256-275; CERTEAU, Michel de. A invenção do cotidiano. 1. artes de fazer (1990). Petrópolis: Vozes, 1994. p. 201-203.

${ }^{125}$ ROCHA, Agenor Miranda. Op. cit., p. 18, 31-34.

${ }^{126}$ SODRÉ, Muniz. Op. cit., p. 149.

${ }^{127}$ Idem, ibidem, p. 26.

${ }^{128}$ BARROS, José Flávio Pessoa de. Op. cit., p. 32-33.

${ }^{129}$ ROCHA, Agenor Miranda. Op. cit., p. 31.

${ }^{130}$ Idem, ibidem, p. 31-33.

${ }^{131}$ Idem, ibidem, p. 32.

${ }^{132}$ Idem, ibidem, p. 33.

${ }^{133}$ Idem, ibidem, p. 31.

${ }^{134}$ Idem, ibidem. 
${ }^{135}$ CONDURU, Roberto. Arte Afro-Brasileira. Rio de Janeiro: C/Arte, 2007. p. 31-33.

${ }^{136}$ BARROS, José Flávio Pessoa de. Op. cit., p. 33.

${ }^{137}$ Disponível em <www.iphan.gov.br/ans>. Acesso em 10 de junho de 2010.

${ }^{138}$ Apud FERRAZ, Eucanaã. O tombamento de um marco da africanidade carioca: a Pedra do Sal. Revista do Patrimônio, IPHAN, n. 25, 1997. p. 336.

139 SOARES, Mariza de Carvalho. Nos atalhos da memória - Monumento a Zumbi. In: KNAUSS, Paulo (Org.). Cidade vaidosa: imagens urbanas do Rio de Janeiro. Rio de Janeiro: 7Letras, 1999. p. 126.

${ }^{140}$ Disponível em <www.iphan.gov.br/ans>. Acesso em $1^{\circ}$ de junho de 2010. A respeito dessa coleção, ver também MAGGIE, Yvonne. Op. cit., p. 257-267; CONDURU, Roberto (Org.). Relicário multicor. A coleção de cultos afro-brasileiross do Museu da Polícia Civil do Estado do Rio de Janeiro. Rio de Janeiro: Centro Cultural Municipal José Bonifácio; Museu da Polícia Civil do RJ; Instituto de Artes da UERJ, 2008.

\section{Referências bibliográficas}

ALVAREZ, Marcos César; Fernando Afonso Salla; Luís Antônio F de Souza. A sociedade e a Lei: o Código Penal de 1890 e as novas tendências penais na primeira República”. Justiça e História, Porto Alegre, v. 3, n. 6, 2003.

ALVES, Marcelo. As aventuras do homus cinematographicus (estrelando: João do Rio). In: DOMINGUES, Chirley; ALVES, Marcelo (Orgs.). A cidade escrita: literatura, jornalismo e modernidade em João do Rio. Itajaí: Universidade do Vale do Itajaí, 2005.

ARAÚJO, Ari. Entrevista com Agenor Miranda, Revista do Patrimônio Histórico e Artístico Nacional, Rio de Janeiro, IPHAN, n. 25, 1997.

BANDEIRA, Manuel. Mangue. In: ___ Libertinagem. Rio de Janeiro: Ed. do autor, 1930.

BARROS, José Flávio Pessoa de. O banquete do rei... Olubajé: uma introdução à música afro-brasileira. Rio de Janeiro: Ao Livro Técnico, 2000.

CERTEAU, Michel de. A invenção do cotidiano. 1. Artes de fazer (1990). Petrópolis: Vozes, 1994.

CONDURU, Roberto (Org.). Relicário multicor. A coleção de cultos afro-brasileiros do Museu da Polícia Civil do Estado do Rio de Janeiro. Rio de Janeiro: Centro Cultural Municipal José Bonifácio; Museu da Polícia Civil do RJ; Instituto de Artes da UERJ, 2008.

. Arte Afro-Brasileira. Rio de Janeiro: C/Arte, 2007.

COSSARD, Gisèle Omindarewá. Awó: o mistério dos orixás. Rio de Janeiro: Pallas, 2006.

FERNANDES, Nilo; FERNANDES, Elizabeth; VIDAL, Marcelo (Orgs.). Pai Zezito d'Oxum. A chegada da nação Ijexá no Rio de Janeiro. Rio de Janeiro: s.e., 2005.

FERRAZ, Eucanaã. O tombamento de um marco da africanidade carioca: a Pedra do Sal. Revista do Patrimônio, IPHAN, n. 25, 1997.

FORTY, Adrian. Space. In: Words and buildings. A vocabulary of modern architecture. London: Thames \& Hudson, 2000.

GOMES, Tiago de Melo. Para além da casa de Tia Ciata: outras experiências no universo cultural carioca, 18301930. Afro-Asia, Salvador, UFBA, v. 29-30, 2003.

LÍRIO, Alba (Org.). Heitor dos Prazeres: sua arte e seu tempo. Rio de Janeiro: ND Comunicação, 2003.

MAGGIE, Yvonne. Medo do feitiço: relaçôes entre magia e poder no Brasil. Rio de Janeiro: Arquivo Nacional, 1992.

MARRA, Heloísa. Pai de todos. O Globo, Rio de Janeiro, 28/08/2004.

MOURA, Roberto M. No princípio, era a roda: um estudo sobre samba, partido-alto e outros pagodes. Rio de Janeiro: Rocco, 2004.

Tia Ciata e a Pequena África no Rio de Janeiro. Rio de Janeiro: Secretaria Municipal de Cultura, Departamento Geral de Documentação e Informação Cultural, Divisão de Editoração, 1995.

NETTO, Márcia Ferreira (Org.). Mapeamento dos terreiros de candomblé do Estado do Rio de Janeiro. Rio de Janeiro: IPHAN, 2010. CD-ROM. 
PARES, Luiz Nicolau. Nota 6 do texto de apresentação. In: TOBIOBÁ, João Batista dos Santos. 21 cartas e um telegrama de Mãe Aninha a suas filhas Agripina e Filhinha, 1935-1937. Afro-Asia, Salvador, UFBA, v. 36, 2007. PRANDI, Reginaldo. Linhagem e Legitimidade no candomblé paulista. Revista Brasileira de Ciências Sociais, São Paulo, ANPOCS, n. 14, 1990.

Modernidade com feitiçaria: candomblé e umbanda no Brasil do século XX. Tempo Social, São Paulo, USP, v. 2, n. $1,1^{\circ}$ sem. 1990.

REBOUÇAS FILHO, Diógenes. Pai Agenor. Salvador: Corrupio, 1998.

REIS FILHO, Nestor Goulart dos. Quadro geral da arquitetura no Brasil (1970). São Paulo: Perspectiva, 1983. RIO, João do. As religiōes do Rio. (1904). Rio de Janeiro: José Olympio, 2006.

ROCHA, Agenor Miranda. As naçôes Kêtu: origens, ritos e crenças. Os candomblés antigos do Rio de Janeiro. (1994). Rio de Janeiro: Mauad, 2000.

SILVA, Yara. Tia Carmem: negra tradição da Praça Onze. Rio de Janeiro: Garamond, 2009.

SISSON, Rachel. Marcos históricos e configuraçôes espaciais. Um estudo de caso: os centros do Rio de Janeiro. Arquitetura Revista, Rio de Janeiro, FAU-UFRJ, v. 4, 2/ sem. 1986.

SOARES, Mariza de Carvalho. Nos atalhos da memória - Monumento a Zumbi. In: KNAUSS, Paulo (Org.). Cidade vaidosa: imagens urbanas do Rio de Janeiro. Rio de Janeiro: 7Letras, 1999.

SODRÉ, Muniz. O terreiro e a cidade. A forma social negro-brasileira. Salvador: Secretaria da Cultura e Turismo; Imago, 2002.

SODRÉ, Muniz; LIMA, Luiz Filipe. Um vento sagrado: história de vida de um adivinho da tradição nagô-kêtu brasileira. Rio de Janeiro: Mauad, 1996.

VILHENA, Luís Rodolfo. A Babel da crença: o campo religioso carioca em João do Rio. In:

Ensaios de antropologia. Rio de Janeiro: EdUerj, 1997.

\section{RESUMO}

$O$ artigo analisa o processo de constituição das comunidades de candomblé no Rio de Janeiro, desde o fim do século XIX. Partindo de uma divisão desse processo em quatro momentos, são propostos três tipos de (des)continuidade para as trajetórias dessas comunidades. Também são analisadas a distribuição dessas comunidades no território do Rio de Janeiro e a tipologia arquitetônica que resulta de práticas menos morfológicas e mais estruturais de reconfiguração do ambiente fisico. Ao final, é discutida a condição dessas comunidades como patrimônio cultural e sua inserção no processo de preservação de sitios, edifícios e objetos referentes à afrodescendência no Rio de Janeiro.

Palavras-chave: terreiro; candomblé; religiōes afro-brasileiras; Rio de Janeiro.

\section{ABSTRACT}

The paper examines the formation process of Candomble communities in Rio de Janeiro, since the late nineteenth century. Starting from a division of this process into four stages, we propose three types of (dis)continuity for the trajectories of these communities. We also analyze the distribution of these communities in the Rio de Janeiro territory and the architectural typology that results from physical environment reconfiguration practices which are less morphological and more structural. Finally, we discuss the condition of these communities as cultural heritage and their place in the process of preservation of sites, buildings and objects related to the African lineage in Rio de Janeiro.

Keywords: terreiro; Candomblé; African-Brazilian religions; Rio de Janeiro. 


\section{Anexo 1}

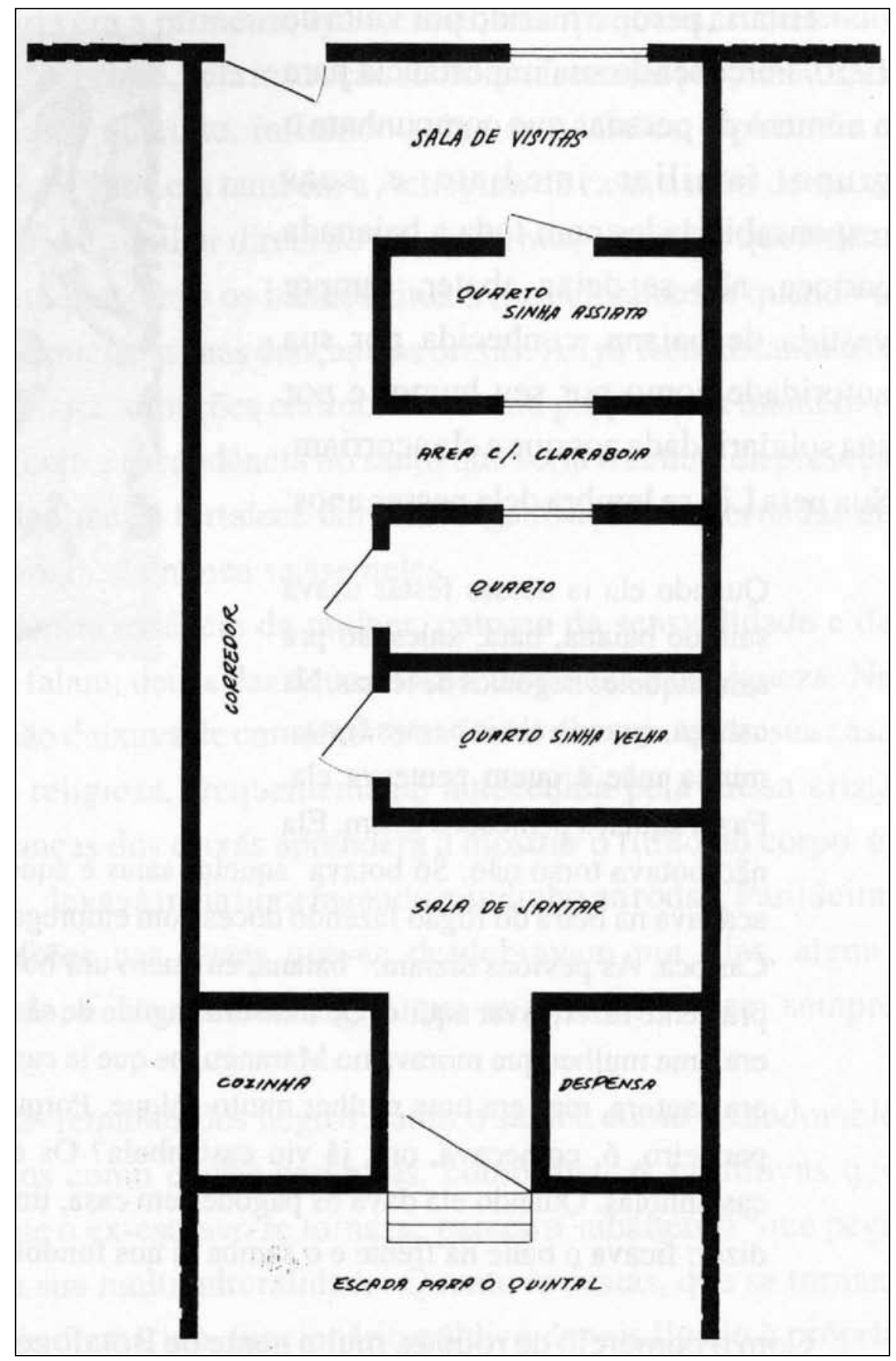

Planta da casa de Tia Ciata conforme depoimento dos parentes que lá conviveram. Arquivo Francisco Duarte. Fonte: MOURA, Roberto M. Tia Ciata e a Pequena África no Rio de Janeiro. Rio de Janeiro: Secretaria Municipal de Cultura, Departamento Geral de Documentação e Informação Cultural, Divisão de Editoração, 1995. 


\section{Anexo 2}

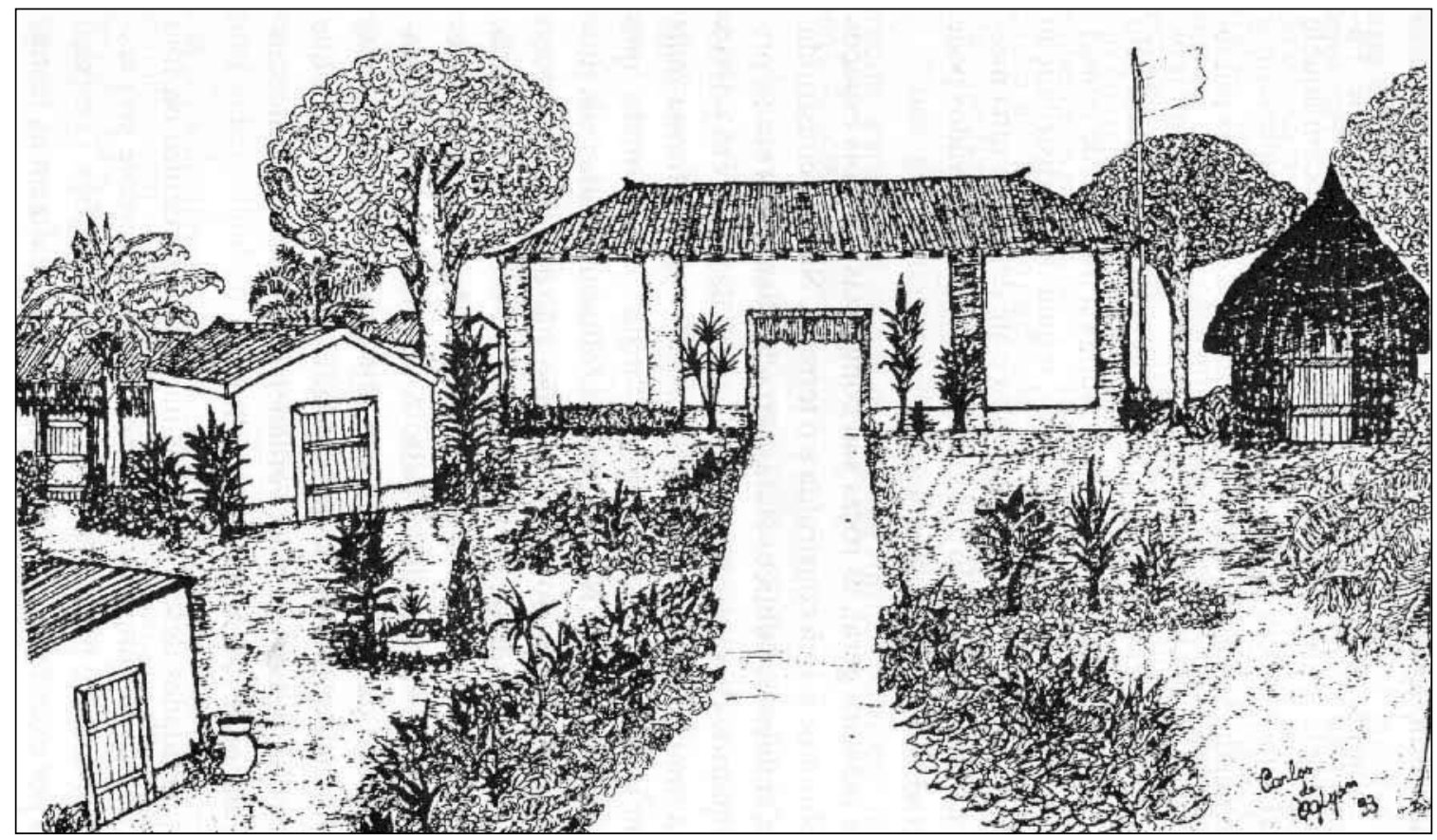

Disposição hipotética de um terreiro, tendo ao centro o barracão e à sua volta os quartos dos orixás. Fonte: ROCHA, Agenor Miranda. As naçôes Kêtu: origens, ritos e crenças.

Os candomblés antigos do Rio de Janeiro. (1994). Rio de Janeiro: Mauad, 2000. 